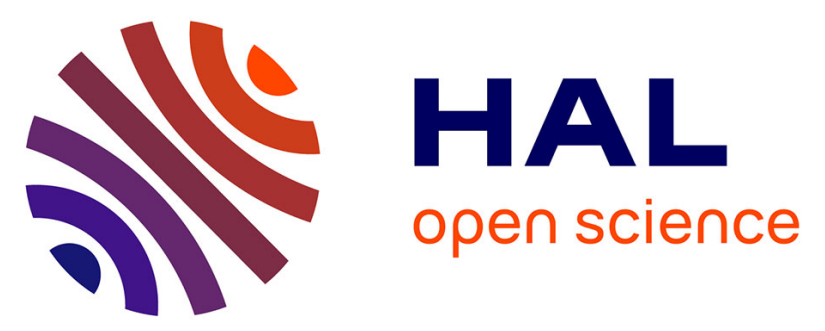

\title{
The clinical spectrum of inherited diseases involved in the synthesis and remodeling of complex lipids. A tentative overview
}

Àngels Garcia-Cazorla, Fanny Mochel, Foudil Lamari, Jean-Marie Saudubray

\section{- To cite this version:}

Àngels Garcia-Cazorla, Fanny Mochel, Foudil Lamari, Jean-Marie Saudubray. The clinical spectrum of inherited diseases involved in the synthesis and remodeling of complex lipids. A tentative overview. Journal of Inherited Metabolic Disease, 2015, 38 (1), pp.19-40. 10.1007/s10545-014-9776-6 . hal01103255

\section{HAL Id: hal-01103255 \\ https://hal.sorbonne-universite.fr/hal-01103255}

Submitted on 14 Jan 2015

HAL is a multi-disciplinary open access archive for the deposit and dissemination of scientific research documents, whether they are published or not. The documents may come from teaching and research institutions in France or abroad, or from public or private research centers.
L'archive ouverte pluridisciplinaire HAL, est destinée au dépôt et à la diffusion de documents scientifiques de niveau recherche, publiés ou non, émanant des établissements d'enseignement et de recherche français ou étrangers, des laboratoires publics ou privés. 


\section{The clinical spectrum of inherited diseases involved in the synthesis and remodeling of complex lipids. A tentative overview.}

GARCIA-CAZORLA Àngels ${ }^{1}$, MOCHEL Fanny ${ }^{2,3,4}$, LAMARI Foudil ${ }^{2,3}$ SAUDUBRAY Jean-Marie ${ }^{2}$

${ }^{1}$ Department of Neurology, Neurometabolic unit, Hospital Sant Joan de Déu and CIBERER, ISCIII, Barcelona, Spain

${ }^{2}$ Bioclinic and genetic Unit of Neurometabolic diseases, Pitié-Salpêtrière Hospital, (APHP), Paris 75013, France

${ }^{3}$ Department of Metabolic Biochemistry. Pitié-salpêtrière Hospital (APHP), Paris 75013, France.

${ }^{4}$ Inserm U 1127, CNRS UMR 7225, Sorbonne Universités, UPMC Univ Paris 06 UMR S 1127, Institut du Cerveau et de la Moelle épinière, ICM, F-75013, Paris, France

${ }^{5}$ Department of Genetic, Pitié-Salpêtrière Hospital, (APHP), Paris 75013, France

\section{Corresponding author:}

J. M. Saudubray

22 Rue Juliette Lamber,

Paris 75017, France

e-mail: imsaudubray@orange.fr

Angeles Garcia Cazorla: agarcia@hsjdbcn.org ; Fanny Mochel:

fanny.mochel@upmc.fr ; LAMARI Foudil: foudil.lamari@psl.aphp.fr

Running title: Clinical presentations of inherited defects in complex lipids biosynthesis

\section{ETHICAL STANDARD STATEMENTS}

Angels Garcia Cazorla, Fanny Mochel, Foudil Lamari and Jean-Marie Saudubray declare that they have no conflict of interest. This article does not contain any studies with human or animal subjects performed by the any of the authors. Angels Garcia Cazorla, Fanny Mochel and JM Saudubray contributed equally to the work for conception, design, drafting and tables. Foudi Lamari helped for documentation and references and revising the manuscript. JM Saudubray is guarantor for the article. 


\section{Abstract}

Over one hundred diseases related to inherited defects of complex lipids synthesis and remodeling are now reported. Most of them were described within the last 5 years. New descriptions and phenotypes are expanding rapidly. While the associated clinical phenotype is currently difficult to outline, with only few patients identified, it appears that all organs and systems may be affected. The main clinical presentations can be divided into (1) Diseases affecting the central and peripheral nervous system. Complex lipid synthesis disorders produce prominent motor manifestations due to upper and/or lower motoneuron degeneration. Motor signs are often complex, associated with other neurological and extra-neurological signs. Three neurological phenotypes, spastic paraparesis, neurodegeneration with brain iron accumulation and peripheral neuropathies, deserve special attention. Many apparently well clinically defined syndromes are not distinct entities, but rather clusters on a continuous spectrum, like for the PNPLA6-associated diseases, extending from Boucher-Neuhauser syndrome via Gordon Holmes syndrome to spastic ataxia and pure hereditary spastic paraplegia; (2) Muscular/cardiac presentations; (3) Skin symptoms mostly represented by syndromic (neurocutaneous) and non syndromic ichthyosis; (4) Retinal dystrophies with syndromic and non syndromic retinitis pigmentosa, Leber congenital amaurosis, cone rod dystrophy, Stargardt disease; (5) Congenital bone dysplasia and segmental overgrowth disorders with congenital lipomatosis; (6) Liver presentations characterized mainly by transient neonatal cholestatic jaundice and non alcoholic liver steatosis with hypertriglyceridemia; and (7) Renal and Immune presentations. Lipidomics and molecular functional studies could help elucidating the mechanism(s) of dominant versus recessive inheritance observed for the same gene in a growing number of these disorders.

Key words : Complex lipids, phospholipids, inborn errors of metabolism, spastic paraplegia, neurodegeneration with brain iron accumulation, peripheral neuropathy, ichthyosis, retinal dystrophy, chondrodysplasia, hepatic steatosis.

\section{Introduction}


The quantitative importance of lipids in the nervous system makes the brain and peripheral nerves a privileged target for defects of complex lipids synthesis and remodeling. However, besides the role of complex lipids in neurological functions and signaling, this review highlighs the importance of these molecules in photoreceptor function, the epidermal water barrier, bone and liver metabolism. This chapter is an attempt to give a clinical overview of this new group of IEM focusing on neurological, muscular, cardiac, ophthalmological, dermatological, orthopedic and hepatic presentations.

\section{Neurological presentations}

Both central (CNS) and peripheral nervous systems are frequently involved in complex lipid synthesis and remodeling disorders. Careful grouping of patients in well-defined neurological syndromes is a practical and useful approach for clinicians (Tables 1 and 2). However, due to the rapidly growing number of diseases and the expanding phenotype of many of these diseases, this approach needs a constant update. As general messages, we wish to highlight the following points:

- Complex lipid synthesis and remodeling disorders produce prominent motor manifestations due upper and/or lower motoneuron degeneration. In fact, these movement disorders are the most remarkable neurological presentations in this category of diseases. Motor signs are often complex, associated with other neurological and extra-neurological signs.

- These disorders should be considered in patients with cerebral-palsy like phenotype, spastic paraparesis, ataxia, NBIA (neurodegeneration associated with brain iron accumulation) and peripheral neuropathy of unknown origin.

- In general, psychiatric disturbances are rare. They have been described in different NBIA, especially as late-onset manifestations, but they rarely appear in other types of complex lipid biosynthesis disorders.

- Epilepsy is also rare as a prominent sign; however, there are some defects that produce early severe refractory epilepsy.

- Developmental delay (DD) and intellectual disability (ID) are commonly present, as in many other neurometabolic diseases, but in general associated with other neurological and extra-neurological signs as "syndromic mental retardation". These additional signs are often useful to the diagnostic approach. Additionally, one 
interesting message learnt from these IEM is the inclusion of serum alkaline phosphatase in the metabolic work-up of mental retardation for the detection of GPIanchor-synthesis defects (Krawitz et al, 2013). Three neurological phenotypes, spastic paraparesis, NBIA and peripheral neuropathies, deserve especial attention (Tables 1 and 2).

\section{Hereditary spastic paraparesis (HSP) - Table 1}

HSP is a heterogeneous group of genetic disorders in which the main feature is progressive spasticity in the lower limbs due to pyramidal tract dysfunction as a result of a 'dying back' degeneration of the cortico-spinal tracts. The critical role of complex lipids in signal transduction and membrane rigidity/fluidity may partly explain how defects in synthesis and remodeling of these lipids often lead to the degeneration of some of the longest, and therefore most vulnerable, axons in the CNS. HSP refers to a syndrome that includes lower extremity weakness and spasticity, each of varying degree, age of onset and progression. There are more than 50 genetic types of HSP, many of them described in the last years (Lo Giudice T et al. 2014). They are classified clinically as "pure" or "uncomplicated" and "complex" or "complicated" (Harding 1983). While some genetic types of HSP usually manifest as "uncomplicated" - e.g. SPG4 HSP due to spastin gene mutation, the single most common form of autosomal dominant HSP -, other genetic types usually present as complex HSP syndromes (Fink, 2013). In general, HSP due to complex lipid biosynthesis defects are autosomal recessive and complicated forms of HSP. Cerebellar involvement, axonal neuropathy, ichthyosis and ocular abnormalities are amongst the most commonly associated symptoms, together with abnormal brain MRI, especially thin corpus callosum. Rather "pure" HSP, although not invariably, can be observed in SPG28 due to phospholipase A1 deficiency and mutations in DDHD1 (Bouslam et al, 2005) (Liguori et al, 2014) as well as SPG56 due to cytochrome P450 hydroxylase deficiency and mutations in CYP2U1 (Tesson et al, 2012). About 13 different genes associated with HSP and defects in lipid biosynthesis and remodeling have been described until now. They participate in different biological functions, especially phospholipid remodelling (PNPLA6, CYP2U1, DDHD1 and DDHD2), fatty acid hydroxylation (CYP2U1) as well as sphingolipids biosynthesis (FA2H, B4GALNT1). 


\section{Neurodegeneration with Brain Iron Accumulation (NBIA) - Table 1}

NBIA syndromes represent a group of degenerative extrapyramidal monogenic disorders with accumulation of iron in the brain, usually in the basal banglia (Gregory and Hayflick 2011). In general, NBIA cause progressive dystonia, bulbar symptoms and pyramidal signs in young children whereas parkinsonism usually appears later. Cognitive decline occurs in some subtypes of NBIA, but more often cognition is relatively spared. Cerebellar atrophy is a frequent finding. So far, 10 different genetic forms have been described (Levi et al, 2014). Two forms are linked to mutations in genes directly involved in iron metabolism: neuroferritinopathy (FTL gene) and aceruloplasminemia - where the ceruloplasmin gene product is defective. In the other forms, the link with iron metabolism is not evident. The biochemical pathways involving lipid metabolism and membrane/organelles (mitochondria) remodeling seem to play an important mechanistic role in NBIA disorders. At least 4 genes, PANK2, PLA2G6, COASY and FA2H, encode proteins involved in lipid metabolism. The protein encoded by c19orf12 is linked to the mitochondrial outer membrane and is presumably connected with lipid metabolism although it has not been completely characterized yet (Hartig et al., 2011).(Tiranti this issue)

\section{Peripheral neuropathies - Table 2}

The diagnosis of peripheral neuropathies, rely on clinical and electrophysiological criteria. The general classification depends on whether there is an involvement of large fibers - i.e. motor weakness, loss of deep reflexes, muscle atrophy, sensory ataxia - versus small fibers - autonomic dysfunction, abnormal temperature sensibility pinprick loss - and whether the neuropathy is predominantly demyelinating or axonal. The lipid composition of myelin and transport of lipid-associated myelin proteins contribute to the observed vulnerability of myelin in lipid metabolism disorders (Chrast et al, 2011). Currently, more than 20 genes have been linked to IEM of lipid biosynthesis and remodeling defects. Different subtypes of peripheral neuropathies have been described in these disorders. Most of them are associated with other neurological and extra-neurological sings such as spastic paraparesis, white matter abnormalities, ocular and hearing impairment. However, peripheral neuropathy may be the presenting and/or predominant symptom in some of these diseases. Likewise, diseases of complex lipids biosynthesis and remodeling may 
present with:

sensory and autonomic neuropathies, especially defects in serine metabolism either with an early onset - then associated with a global encephalopathy - or with an onset during adolescence to adulthood - with a less severe phenotype (Dick 1993; Rotthier et al. 2012; Murphy et al, 2013; Suh et al, 2013, 2014).

demyelinating neuropathies, mainly found in peroxisomal defects such as biogenesis defects related to PEX genes, adrenomyeloneuropathy, X-linked adrenoleukodystrophy and Refsum disease - although peroxisomal diseases can also manifest with axonal neuropathies

axonal neuropathies, often associated with HSP and usually sharing common pathological pathways with HSP.

\section{Muscular and cardiac symptoms - Table 3}

Complex lipid synthesis and remodeling disorders may present with the following skeletal and cardiac muscle predominant manifestations:

- Recurrent rhabdomyolysis with myoglobinuria and myalgia. This is a wellrecognized presentation of beta-oxidation defects such as LCHAD and TFP deficiencies (Olpin et al, 2005), as well as Lipin-1 deficiency (Michot et al, 2010). These episodes are frequently triggered by catabolic or other stressful situations. A rare peroxisomal defect, racemase deficiency, has been reported as a cause of recurrent rhabdomyolysis in adults (Kapina et al, 2010).

- Childhood myopathy mimicking congenital dystrophy, with or without heart involvement. Isolated muscle forms include a severe myopathic phenotype at birth due to 3-hydroxyacyl-CoA dehydratase 1 (PTPLA) deficiency (Muhammad et al, 2013) and the Chanarin-Dorfman syndrome (alpha/beta hydrolase 5 (ABHD5) deficiency). Myopathies with variable cardiac involvement encompass (i) an early onset form with mental retardation and abnormal mitochondrial morphology - i.e. choline kinase beta (CHKB) deficiency (Mitsuhashi et al, 2011), (ii) severe early encephalopathies with seizures and associated signs - i.e. defects in dolichol metabolism (Lefeber et al, 2011, Barone et al, 2012); (iii) Sengers syndrome; and (iv) 
an adult onset myopathy and cardiomyovasculopathy - i.e. neutral lipid storage disease or triglyceride deposit (PNPLA2) (Kaneko et al, 2014).

- Primary or prominent cardiac presentations revealed by dilated or hypertrophic cardiomyopathy, such as DK1 mutations (Kapusta et al, 2012), Barth syndrome (Clarke et al, 2013) and Sengers syndrome (Mayr et al, 2012).

\section{Ophthalmological presentations - Table 4}

\section{Cataract}

Lens membrane contains the highest cholesterol content of any known membrane, indicating the importance of normal cholesterol metabolism in lens maintenance. At least 3 inborn errors of cholesterol biosynthesis - mevalonate kinase deficiency, Conradi Hunermann syndrome, Smith Lemli Opitz syndrome - and one disease of bile acids synthesis - cerebrotendinous xanthomatosis - may be associated with opacities of the crystalline lens. Syndromic cataracts may also be observed in several other IEM related to complex lipids synthesis, either as a diagnostic sign or as an isolated presenting sign like in Lowe syndrome.

Retinal dystrophies - retinitis pigmentosa, Leber congenital amaurosis, early onset retinal dystrophy and Stargardt disease

There are over four hundred known inherited diseases in which the retina, macula or choroids are substantially involved (Rattner et al 1999 ; Retnet).

Retinitis pigmentosa (RP) is the name commonly given to a group of diseases with degeneration of the retina leading to a progressive visual field loss, night blindness and abnormal or non recordable electroretinogram. In typical RP, rod photoreceptors are affected more severely than cones early in the disease. A deficiency in dim light is often the first visual symptom and is due to the degeneration or malfunctioning of rods throughout the retina. Diffuse loss of both rod and cone sensitivity leads to blindness. Biochemical studies have revealed that the pathophysiology related to the degeneration of the photoreceptor cells of the retina can be divided into 3 large groups: (i) a primary biochemical defect inherent to the photoreceptor cells; (ii) a primary biochemical defect in neighboring retinal cells such as the retinal pigment epithelium (RPE) - a CNS derivative that separates the retina from the choroidal circulation; and (iii) a peculiar sensitivity of the photoreceptors or the retinal pigment epithelium to a generalized metabolic defect (Drijja 2001). In secondary RP, the 
retinal degeneration is associated with other systemic abnormalities, including neurological dysfunction, hearing loss, dysmorphism, skin abnormalities, nephropathy and myopathy. Although the basic pathophysiology of RP is not known, the occurrence of RP in metabolic disorders suggests that it might be induced by abnormal metabolic products, errors of synthetic pathways or deficient energy metabolism (Poll-The et al 1992, Poll-The et al 2003). The lipid phase of the photoreceptor outer segment membrane is essential to the photon capturing and signaling functions of rhodopsin. The rearrangement of phospholipids in the bilayer accompanies the formation of the active intermediates of rhodopsin following photon absorption. ABCA4 is implicated in the transport of a retinal phospholipid compound across membranes of the photoreceptor outer segment disc. All-trans retinal released from rhodopsin is reduced to all-trans retinol and subsequently shuttled to the RPE cells where it is sequentially converted back to 11-cis retinal for the regeneration of rhodopsin (Molday et al 2010). These last steps involve consecutively lecithin:retinol acyl transferase (LRAT) and RPE 65 isomerase. All these steps have been found implicated in various forms of RP and Leber congenital amaurosis (LCA) (Mackay et al 2013).

LCA is a severe retinal dystrophy with infantile onset that presents with profound visual impairment, inability to fixate and nystagmus from birth or within the first few weeks of life. It is the most severe form among the spectrum of these disorders arising within the first few years of life and affecting both rod and cone photoreceptors, also called childhood or early onset retinal dystrophy (EORD) (Gu et al, 1997). The term juvenile RP has also been used to describe EORD. Autosomal recessive $\mathrm{RP}$ falls into this spectrum of disorders with onset typically later in childhood or beyond. Depending on the age at diagnosis, the retinal appearance may be normal or there may be a variety of abnormalities including vascular narrowing, macular atrophy, peripheral white dots at the level of the RPE and retinal pigmentation. The full-field electroretinogram (ERG) is usually non-detectable with conventional ERG testing or severely decreased before the age of 1 year. LCA, EORD and RP may be considered as a continuum spectrum of retinal dystrophies, in which LCA represents the most severe form due to its age of onset and functional outcome.

Stargardt disease is the most common autosomal recessive, early onset macular dystrophy. Affected individuals display significant loss in central vision with a marked 
reduction in visual acuity in their first or second decade of life. Progressive decrease

\section{Optic nerve degeneration - optic atrophy and glaucoma}

Hereditary optic atrophy $(\mathrm{OA})$ is common in neurodegenerative diseases due to IEM, especially white matter diseases and energy deficiencies, and deserves an extensive work-up (Saudubray et al, 2012). The OA and cortical blindness that occur early in the course of Krabbe disease - globoid cell leukodystrophy, galactosylceramid lipidosis - are a direct consequence of the severe loss of myelin and oligodendroglia that is characteristic of this disorder. Although the OA develops early in the disease course, it is usually overshadowed by the neurological deterioration. OA is also frequent in metachromatic leukodystrophy and may result in severely impaired vision. $O A$ is a frequent early presenting sign of primary - Leber hereditary optic neuropathy, respiratory chain deficiencies, pyruvate dehydrogenase deficiency, biotinidase deficiency, Costeff optic atrophy syndrome - or secondary - organic acidurias - mitochondrial dysfunction. By contrast, OA appears to be a rather rare ocular finding in disorders of complex lipids synthesis compared to retinal 
dystrophies. Nonetheless, visual loss and $O A$ are early presenting sign in several a very frequent and early significant sign in some NBIA - INAD and MPAN -,in which an impairment of mitochondrial function is strongly suspected in disease development and/or progression. In this respect, it is relevant that the mitochondriaassociated membrane of the endoplasmic reticulum is major site of phospholipid biosynthesis and trafficking (Tiranti this issue).

Glaucoma is characterized by the progressive loss of visual fields due to the degeneration of the optic nerve, usually associated with increased intraocular pressure. Early onset glaucoma is a major diagnostic sign in Charcot Marie Tooth disease type 4B2, due to mutations in the gene SBF2 that is involved in phosphoinositide metabolism.

\section{Dermatological presentations - Table 5}

About 30 inherited disorders of complex lipids synthesis, remodeling ,catabolism and transport presenting with ichthyosis have been described so far. According to the most recent ichthyosis consensus conference (Oji et al 2010), inherited ichthyoses belong to a large and heterogeneous group of mendelian disorders of cornification and involve the entire integument. This classification remains clinically based and distinguishes between syndromic and non syndromic ichthyosis forms. Bullous ichthyosis/epidermolytic hyperkeratosis was redefined as keratinopathic ichthyosis. Autosomal recessive congenital ichthyosis (ARCl) refers to harlequin ichthyosis, lamellar ichthyosis, and congenital ichthyosiform erythroderma. At least 6 inherited lipids synthesis disorders are responsible for non syndromic $\mathrm{ARCl}$, all but one linked to epidermal lipase $\mathrm{N}$ deficiency - presenting at birth with a collodion baby aspect. The vast majority of ichthyosis linked to complex lipids disorders present as neuro-cutaneous syndromes, chondrodysplasia punctata or multiple congenital anomalies - CDG syndromes, neuro laxova syndrome. Among the neuro-cutaneous syndromes comprising spastic paraparesis, Sjögren-Larsson syndrome - ALDH deficiency - presents at birth with a very severe pruriginous ichthyosis that responds dramatically to Zileuton (Willemsen et al 2001). Sterol methyl-C4 oxidase, a sterol metabolism disorder, is another treatable ichthyosis with a spectacular improvement on statin and cholesterol supplement (He et al 2011). 
Erythrokeratodermia variabilis (EKV), which is characterized by migratory erythematous patches and more fixed, symmetric hyperkeratotic plaques often with palmo-plantar involvement, is genetically heterogeneous; in $50 \%$ to $65 \%$ of cases, it can be caused by mutations in GJB3 coding for a gap junction protein connexin. Previously, erythrokeratodermia was differentiated from the ichthyosis group as, in most cases, it is not generalized. However, the majority of the participants to the consensus conference thought that the inclusion of EKV into the ichthyosis classification is appropriate. Interestingly, an early EKV associated with autosomal dominant late onset spinocerebellar ataxia has been recently shown to be caused by ELOVL4 heterozygote mutation (Cadieu-Dion et al 2014).

Another intriguing skin manifestation of complex lipids metabolism disorders is the inflammatory dermatosis - i.e. Sweet syndrome - observed in Majeed syndrome due to Lipin 2 deficiency (Ferguson et al 2005), which highlights the potential role of complex lipids in inflammation (Csaki 2013).

\section{Orthopedic presentations - Table 6}

Over 20 inborn errors affecting the synthesis or remodeling of phosphatidylcholine, phosphatidylserine, phosphatidylinositol, plasmalogens or cholesterol present with major bone and cartilage involvement. Schematically, 3 clinical entities may be recognized: congenital bone dysplasia, overgrowth disorders and inflammatory presentations.

\section{Congenital bone dysplasia}

Beside rhizomelic chondrodysplasia punctate (Brites this issue) and the already wellknown defects of cholesterol and plasmalogen biosynthesis responsible for a variety of bone dysplasia and polymalformative syndromes (Waterham 2012), several original entities affecting phospholipids metabolism have been recently described. They involve mostly the synthesis, transport or activating pathways of phosphoserine (Wortmann this issue) and phosphatidyl inositides (Balla 2013): (i) Lenz-Majewski syndrome, a sclerosing bone dysplasia is caused by a gain of function mutation in the gene encoding phosphatidylserine synthase 1 (PTDSS1), which impairs the negative feedback regulation of the enzyme by its reaction product phosphoserine (Sousa et al, 2014, Wortmann this issue); (ii) spondylometaphyseal 
dysplasia with cone-rod dystrophy is caused by mutations in the gene encoding cholinephosphatase cytidylyltransferase A (PCYT1A), a key enzyme in phosphatidylcholine biosynthesis (Yamamoto et al 2014; Wortmann this issue) - of note, a late onset form of PCCT1A mutations display a very different phenotype without any bone involvement (Payne et al, 2014); (iii) Yunis-Varon syndrome presenting with cleidocranial dysplasia and skeletal abnormalities has been recently linked to mutations in FIG4 that encodes a phosphoinositide phosphatase required for the regulation of phosphatidylinositol 3,5-phosphate (PI(3,5)P2) (Campeau et al, 2013); and (iv) opsismodysplasia, a severe chondrodysplasia is due to a deficiency in inositol-1,4,5-triphosphate 5-phosphatase INPPL1 (Huber et al, 2013).

\section{Segmental overgrowth disorders with congenital lipomatosis}

The molecular etiology of somatic overgrowth syndromes has been recently clarified and allowed the clinical delineation and natural history of the PIK3CA-related overgrowth spectrum (Keppler-Noreuil et al 2014; Lindhurst et al 2012). The spectrum of diseases associated with PIK3CA mutations include fibroadipose overgrowth, hemihyperplasia multiple lipomatosis, congenital lipomatous overgrowth, vascular malformations, epidermal nevi, scoliosis/skeletal and spinal syndrome (CLOVES), macrodactyly, and the megalencephaly-capillary malformation syndrome (MCAP). It appears that all these phenotypes have a considerable overlap and are associated with somatic gain of functions of phosphoinositol kinase 3 resulting in an over-activation of the phosphatidylinositol/AKT/mTOR pathway. PIK3CA mutations are detected in affected tissues or cultured cells at varying levels, but not in the blood or saliva. There is not a clear correlation between the mutation level in either tissues or cultured cells to either the type or the severity of the manifestations. Apart from the class IA of PI3Ks, human diseases are rarely caused by activating mutations of inositide lipid kinases. Moreover, loss of function of inositol lipid kinases is rarely seen in human diseases. The only report on an inactivating mutation of the PIP 5kinase I gene was associated with severe developmental abnormalities with perinatal lethality (Narkis et al 2007). Conversely, an increasing number of rare human diseases such as Joubert syndrome, Lowe syndrome, Charcot-Marie-Tooth disease type 4B1 or X-linked myotubular myopathy are linked to phosphoinositide phosphatase defects and cause very specific phenotypes (Balla 2013). 


\section{Inflammatory presentations}

Recurrent aseptic necrosis and medullary infarction of long bones in an inflammatory context are a frequent diagnostic finding in Majeed syndrome and Gaucher disease. These symptoms represent a major clinical concern.

\section{Hepatic presentations - Table 7}

Complex lipids synthesis and remodeling disorders may be associated with 3 preponderant hepatic presentations.

The first presentation is a transient neonatal to early infantile cholestatic jaundice and/or liver failure followed by a neurodegenerative disorder. Beside the well-known Niemann-Pick type C disease (Vanier 2010), cholestatic jaundice may be the first manifestation of several diseases affecting the synthesis of cholesterol and bile acids. In most cases, the jaundice spontaneously resolves but psychomotor delay, peripheral neuropathy and/or motor dysfunction develop during the first decade or even later. In the so-called infantile Refsum disease - a peroxisome biogenesis defect - the neonatal jaundice is commonly followed by a 1 to 3 years phase of failure to thrive with hepatomegaly, osteoporosis and hypocholesterolemia before neurologic symptoms, RP and deafness arise (Poll-The 2007). Megdel syndrome also presents first with recurrent episodes of liver failure, similar to what is seen in mitochondrial DNA depletion syndromes, before the onset of dystonia and a Leighlike encephalopathy (Sarig et al 2013; Wortmann this issue).

Major hepatosplenomegaly is another preponderant diagnostic sign, evocative of many lysosomal disorders involving the catabolism and recycling of complex sphingolipids. Mevalonate kinase deficiency presents early in life with acute recurrent inflammatory crisis, fever, skin rashes, arthralgia, hepatosplenomegaly and severe recurrent anemia (Houten et al 2003).

Finally, non-alcoholic liver steatosis is a presenting sign in several IEM involving triglyceride biosynthesis. Indeed, the liver is a central organ in the regulation of triglycerides metabolism; it participates in triglyceride synthesis, export, uptake and oxidation. Hepatocytes can shift from intensive fatty acid synthesis - in fed state - to rapid fatty acid breakdown - during starvation. Massive fatty liver, partly reversible, is an almost constant finding in many mitochondrial fatty acid oxidation disorders during acute crises (Saudubray et al 1999). Chronic hepatosteatosis, considered as the 
fundamental cause of hepatic injuries, inflammation and fibrosis are often found in individuals with defect in triacylglycerol metabolism. Patients may present (i) either with a preponderant hepatomegaly with hypertriglyceridemia, as observed in individuals with Chanarin-Dorfman syndrome - triglyceride lipase or glycerol-3phosphate dehydrogenase deficiency (Aguilera-Méndez et al, 2013; Wu and Mitchell this issue); or (ii) as a lipodystrophy with insulin resistance and diabetes, like in the Berardinelli-Seip syndrome ( $\mathrm{Wu}$ and Mitchell this issue) and the most recently described late onset form of choline-phosphate cytidylyltransferase A deficiency (Payne et al 2014).

\section{Other presentations}

Several renal presentations have been described so far: (i) Mutations in DGKE result in diacylglycerol kinase epsilon deficiency and cause renal microangiopathies, leading either to a membranoproliferative glomerulonephritis or an early onset atypical haemolytic-uremic syndrome (Lemaire et al 2013; Ozaltin et al 2013; Westland et al. 2014; Wortrmann this issue); (ii) Nephrotic syndrome is a major manifestation of coenzyme $Q$ synthesis defects (Salviati this issue) and a preponderant presenting sign in PLCE1 mutations responsible for the nephrotic syndrome type 3; (iii) Renal Fanconi syndrome with mental retardation and cataract are cardinal signs of Lowe syndrome due to OCRL1 mutations (Attree et al 1992; Suchy et al 2002) - OCRL mutations are also found in some forms of Dent disease without any cataract (Hoopes 2005); (iv) Nephronophthisis may be one of the symptoms observed in Joubert syndrome due to INPP5E mutations, now included in the new emerging group of ciliopathies (Bielas et al 2009); and (v) Renal cysts are a cardinal sign in the hepato-cerebro-renal Zellweger syndrome resulting from peroxisome biogenesis defects.

Disorders of complex lipids biosynthesis may also involve the immune system : (i) PIK3CD mutations cause a combined immune deficiency; (ii), PIK3R1 mutations are responsible for an autosomal recessive agammaglobulinemia; and (iii) the recently described deletions of PLCG2, which encodes phospholipase $C_{\gamma}(2)-$ an enzyme expressed in B cells, natural killer cells and mast cells -, present with cold urticaria, immunodeficiency and autoimmunity (Ombrello et al 2012). 


\section{Conclusion}

This review attempts to give a clinical overview of disorders affecting the synthesis and remodeling of phospholipids and other complex lipids. Many metabolic and genetic factors may account for the clinical diversity of these disorders. The quantitative importance of lipids in the nervous system makes the brain and peripheral nerves a privileged target for these lipids synthetic defects. Mitochondrial membranes that are very rich in cardiolipin and phosphoethanolamine should be particularly vulnerable to mutations affecting these molecules. The tissue specificity of some complex lipid molecules also probably accounts for some specific clinical presentations. Hence the high concentration of cardiolipin in muscle and its very small content in the brain may underlie the predominant muscle/cardiac presentation of Barth syndrome with no or minimal involvement of the nervous system. Similarly, the confinement to skeletal muscles of clinical manifestations of Lipin-1 mutations might be related to the nearly ubiquitous expression of the 2 other LPIN genes (LPIN2 and LPIN3). The constant CNS involvement observed in phospholipase A2 deficiency is probably related to the major and predominant expression of this enzyme in the brain even if the clinical heterogeneity is still poorly understood. It is noteworthy that identical mutations affecting the same enzyme can give rise to very different phenotypes like in ELOVL4 mutations which may present as an autosomal dominant spinocerebellar ataxia with erythrokeratodermia (Cadieux-Dion 2014), a dominant form of Stargardt disease type 3 or a recessive neuro-ichthyotic syndrome resembling a severe presentation of Sjögren-Larsson disease. Another example of such an intriguing phenotypic heterogeneity are mutations in PCYT1A, encoding choline-phosphate cytidylyltransferase $A$, which may present as a spondylometaphyseal dysplasia with cone rod dysfunction or as a congenital lipodystrophy with fatty liver disease but any bone or retina involvement (Payne et al 2014). Tissue specificity might also be responsible for many non syndromic phenotypes, like (i) immune deficiencies syndromes related to mutations in genes specifically expressed in lymphocytes; (ii) congenital ichthyosis related to mutations in genes specifically expressed in keratinocytes such as LIPN encoding epidermal lipase N (Israeli et al. 2011) and PNPLA1 encoding a PNPLA protein involved in glycerophospholipid synthesis (Grall et al. 2012); (iii) retinal dystrophies; or (iv) renal presentations. It must be stressed that many apparently well clinically defined 
syndromes are not distinct entities, but rather clusters on a continuous spectrum like Gordon Holmes syndrome, spastic ataxia and pure HSP. Similarly, LCA, EORD and $\mathrm{RP}$ may be considered as a continuum spectrum of retinal dystrophies. Likewise, mutations in $A B C A 4$ result in a spectrum of related retinal dystrophies including some forms of Stargardt disease.

Awaiting for a more comprehensive overview of this very complex part of cellular metabolism, a clinical approach based on the preponderant presenting symptoms remains therefore the only available one at bedside. The careful grouping of patients in well-defined clinical entities may provide algorithms for orientating metabolic (e.g., lipidomic approaches) and genetic (e.g., exome sequencing) investigations. Of note, these complex molecules synthesis defects are at the crossroad of classical IEM due to an enzymatic block on a catabolic pathway and IEM affecting the synthesis and stability of structural molecules. The concept of complex molecules synthesis defects also opens the window to promising therapeutic trials for example by providing the distal missing compound as it has been successfully done in cerebrotendinous xanthomatosis (Berginer et al 1984), coenzyme Q synthesis defects (Salviati this issue), serine synthesis defects (Méneret et al 2012) and serine metabolism defects involved in de novo biosynthesis of glycosphingolipids (Garofalo et al 2011).

\section{Acknowledgments}

We acknowledge Dr Hans Mayr for the supplementary table "Gene defects in the lipid metabolism and their predominant clinical manifestation". 


\section{References}

Aguilera-Méndez A, Álvarez-Delgado C, Hernández-Godinez D, (2013) Hepatic diseases related to triglyceride metabolism. Mini Rev Med Chem 13:1691-9.

Akiyama M (2010) ABCA12 Mutations and Autosomal Recessive Congenital Ichthyosis: A Review of Genotype/Phenotype Correlations and of Pathogenetic Concepts. Hum Mut 31: 1090-1096.

Aldahmesh MA, Mohamed JY, Alkuraya HS et al (2011) Recessive mutations in ELOVL4 cause ichthyosis, intellectual disability, and spastic quadriplegia. Am J Hum Genet 89: 745-750.

Aleman TS, Soumittra N, Cideciyan AV et al (2009) CERKL mutations cause an autosomal recessive cone-rod dystrophy with inner retinopathy. Invest. Ophthalmol Vis Sci 50:59445954

Almeida AM, Murakami Y, Layton DM et al (2006) Hypomorphic promoter mutation in PIGM causes inherited glycosylphosphatidylinositol deficiency. Nat Med 12:846-51.

Attree O, Olivos IM, Okabe I et al (1992) The Lowe's oculocerebrorenal syndrome gene encodes a protein highly homologous to inositol polyphosphate-5-phosphatase. Nature 358:239-42

Azzedine $\mathrm{H}$, Bolino A, Taieb $T$ et al (2003) Mutations in MTMR13, a new pseudophosphatase homologue of MTMR2 and Sbf1, in two families with an autosomal recessive demyelinating form of Charcot-Marie-Tooth disease associated with earlyonset glaucoma. Am J Hum Genet 72: 1141-1153.

Balla T (2013) Phosphoinositides: Tiny lipids with giant impact on cell regulation. Physiol Rev 93:1019-1137.

Barth PG, Valianpour F, Bowen VM et al (2004) X-linked cardioskeletal myopathy and neutropenia (Barth syndrome): an update. Am J Med Genet A 126:349-54

Barone R, Aiello C, Race V, et al (2012) DPM2-CDG: a muscular dystrophydystroglycanopathy syndrome with severe epilepsy. Ann Neurol 72:550-8

Barwick KE, Wright J, Al-Turki $S$ et al (2012) Defective presynaptic choline transport underlies hereditary motor neuropathy. Am J Hum Genet 91:1103-7.

Below JE, Earl DL, Shively KM et al (2013) Whole-genome analysis reveals that mutations in inositol polyphosphate phosphatase-like 1 cause opsismodysplasia. Am J Hum Genet 92:137-43.

Berginer VM, Salen G, Shefer S (1984) Long-term treatment of cerebrotendinous xanthomatosis with chenodeoxycholic acid. N Engl J Med 311:1649-52.

Bielas SL, Silhavy JL, Brancati F, et al (2009) Mutations in INPP5E, encoding inositol polyphosphate-5-phosphatase E, link phosphatidyl inositol signaling to the ciliopathies. 


\section{Nat Genet 41: 1032-1036}

Bione S, D'Adamo P, Maestrini E et al (1996) A novel X-linked gene, G4.5.(sic) is responsible for Barth syndrome. Nature Genet 12: 385-389.

Blumkin L, Leshinsky-Silver E, Zerem A, Yosovich K, Lerman-Sagie T, Lev D (2014) Heterozygous mutations in the ADCK3 gene in siblings with cerebellar atrophy and extreme phenotypic variability. JIMD 12:103-107

Boccuto L, Aoki K, Flanagan-Steet $\mathrm{H}$ et al (2014) A mutation in a ganglioside biosynthetic enzyme, ST3GAL5, results in salt \& pepper syndrome, a neurocutaneous disorder with altered glycolipid and glycoprotein glycosylation. Hum Mol Genet. 23:418-33.

Boukhris A, Schule R, Loureiro JL et al (2013) Alteration of ganglioside biosynthesis responsible for complex hereditary spastic paraplegia.Am J Hum Genet 93:118-23.

Bouslam N, Benomar A, Azzedine $\mathrm{H}$ et al (2005) Mapping of a new form of pure autosomal recessive spastic paraplegia (SPG28). Ann Neurol 57:567-71

Braverman N, Lin P, Moebius FF, et al (1999) Mutations in the gene encoding 3 betahydroxysteroid-delta 8, delta 7-isomerase cause X-linked dominant Conradi-Hünermann syndrome. Nat Genet 22:291-4.

Cadieux-Dion M, Turcotte-Gauthier M, Noreau A et al (2014) Expanding the clinical phenotype associated with ELOVL4 mutation: study of a large French-Canadian family with autosomal dominant spinocerebellar ataxia and erythrokeratodermia. JAMA Neurol 71:470-5

Campeau PM, Lenk GM, Lu JT et al (2013) Yunis-Varón syndrome is caused by mutations in FIG4, encoding a phosphoinositide phosphatase. Am J Hum Genet 92:781-91

Chiyonobu T, Inoue N, Morimoto M et al (2013) Glycosylphosphatidylinositol (GPI) anchor deficiency caused by mutations in PIGW is associated with West syndrome and hyperphosphatasia with mental retardation syndrome J Med Genet 51:203-7.

Chow CY, Zhang Y, Dowling JJ, et al (2007) Mutation of FIG4 causes neurodegeneration in the pale tremor mouse and patients with CMT4J. Nature 448: 68-72

Chrast R, Saher G, Nave KA, Verheijen MH (2011) Lipid metabolism in myelinating glial cells: lessons from human inherited disorders and mouse models. J Lipid Res 52:419-34.

Cideciyan AV, Haeseleer F, Fariss RN et al (1999) Rod and cone visual cycle consequences of a null mutation in the 11-cis-retinol dehydrogenase gene in man. Vis Neurosci 17:667678

Citterio A, Arnoldi A, Panzeri E et al (2014) Mutations in CYP2U1, DDHD2 and GBA2 genes are rare causes of complicated forms of hereditary spastic paraparesis. J Neurol $261: 373-81$.

Clarke SL, Bowron A, Gonzalez IL et al (2013) Barth syndrome. Orphanet J Rare Dis 12:823.

Clayton PT, Verrips A, Sistermans E et al (2002) Mutations in the sterol 27

hydroxylase gene (CYP27A) cause hepatitis of infancy as well cerebrotendinous 
xanthomatosis. J Inherit Metab Dis 25:501-513

Cormier-Daire V, Delezoide AL, Philip N et al (2003) Clinical, radiological, and chondroosseous findings in opsismodysplasia: survey of a series of 12 unreported cases. J Med Genet 40:195-200.

Csaki LS, Dwyer JR, Fong LG et al (2013), Lipins, lipinopathies, and the modulation of cellular lipid storage and signalling, Progr Lipid Res 52: 305-316

Debray FG, Baguette C, Colinet S et al (2013) Early infantile cardiomyopathy and liver disease: a multisystemic disorder caused by congenital lipodystrophy. Mol Genet Metab. 109:227-9.

den Hollander Al, McGee TL, Ziviello C et al (2009) A homozygous missense mutation in the IRBP gene (RBP3) associated with autosomal recessive retinitis pigmentosa. Invest Ophthalmol Vis Sci 50:1864-1872 .

Derry JM, Gormally E, Means GD et al (1999) Mutations in a delta 8-delta 7 sterol isomerase in the tattered mouse and X-linked dominant chondrodysplasia punctata. Nat Genet. 22:286-90.

Dick KJ1, Eckhardt M, Paisán-Ruiz C et al (2010) Mutation of FA2H underlies a complicated form of hereditary spastic paraplegia (SPG35). Hum Mutat 31:E1251-60.

Drijja TP (2001) Retinitis pigmentosa and stationary night blindness. In Scriver CR, Baudet AL, Sly WS, Valle D, eds; Childs B, Kinzler KW, Vogelstein B, assoc. eds. The Metabolic and Molecular Bases of Inherited Disease, 8th edn. New York: McGraw-Hill, 5903-5933.

Duncan AJ, Bitner-Glindzicz M, Meunier B et al (2009) A nonsense mutation in COQ9 causes autosomal-recessive neonatal-onset primary coenzyme Q10 deficiency: a potentially treatable form of mitochondrial disease. Am J Hum Genet 84:558-566

Dusi S, Valletta L, Haack TB et al (2014) Exome sequence reveals mutations in CoA synthase as a cause of neurodegeneration with brain iron accumulation. Am J Hum Genet 94:11-22.

Eckl KM, Tidhar R, Thiele $\mathrm{H}$ et al (2013 Impaired epidermal ceramide synthesis causes autosomal recessive congenital ichthyosis and reveals the importance of ceramide acyl chain length. J Invest Dermatol. 133:2202-11

Eisenberger T, Slim R, Mansour A et al (2012) Targeted next-generation sequencing identifies a homozygous nonsense mutation in ABHD12, the gene underlying PHARC, in a family clinically diagnosed with Usher syndrome type 3. Orphanet J Rare Dis 2; 7:59.

Ferdinandusse S, Denis S, Clayton PT et al (2000) Mutations in the gene encoding peroxisomal alpha-methylacyl-CoA racemase cause adult-onset sensory motor neuropathy. Nat Genet 24:188-91.

Ferguson PJ, Chen S, Tayeh MK et al (2005) Homozygous mutations in LPIN2 are responsible for the syndrome of chronic recurrent multifocal osteomyelitis and congenital dyserythropoietic anaemia (Majeed syndrome). J Med Genet 42:551-557

Fingert $\mathrm{JH}$, Oh K , Chung $\mathrm{M}$ et al (2008) Association of a novel mutation in the retinol dehydrogenase $12(R D H 12)$ gene with autosomal dominant retinitis pigmentosa. Arch Ophthalmol 126:1301-1307 
Fink JK (2013) Hereditary spastic paraplegia: clinico-pathologic features and emerging molecular mechanisms. Acta Neuropathol 126:307-28.

Fiskerstrand T, H'mida-Ben Brahim D, Johansson S et al (2010) Mutations in ABHD12 cause the neurodegenerative disease PHARC: An inborn error of endocannabinoid metabolism. Am J Hum Genet 87:410-7

Fragaki K, Ait-El-Mkadem S, Chaussenot A et al (2013) Refractory epilepsy and mitochondrial dysfunction due to GM3 synthase deficiency. Eur J Hum Genet 21:528-34

Garofalo K, Penno A, Schmidt BP et al (2011) Oral L-serine supplementation reduces production of neurotoxic deoxysphingolipids in mice and humans with hereditary sensory autonomic neuropathy type 1. J Clin Invest. 121:4735-45.

Grall A, Guaguère E, Planchais S et al (2012) PNPLA1 mutations cause autosomal recessive congenital ichthyosis in golden retriever dogs and humans. Nature Genet 44 $: 140-147$

Gregory A, Hayflick S (2011) Genetics of neurodegeneration with brain iron accumulation. Curr Neurol Neurosci Rep11:254-61.

Gregory A, Hayflick S (2013) Neurodegeneration with brain iron accumulation disorders overview. In: Pagon RA, Adam MP, Bird TD, Dolan CR, Fong CT, Stephens K (eds) Source GeneReviews ${ }^{\text {TM }}$ [Internet]. University of Washington, Seattle, pp 1993-2013

Gross C, Nakamoto M, Yao X, Chan CB et al (2010) Excess phosphoinositide 3-kinase subunit synthesis and activity as a novel therapeutic target in fragile $\mathrm{X}$ syndrome. $\mathrm{J}$ Neurosci. 30:10624-38

Gu SM, Thompson DA, Srikumari CR, (1997) Mutations in RPE65 cause autosomal recessive childhood-onset severe retinal dystrophy. Nat Genet 17:194-7.

Hahn CN, del Pilar Martin M, Schröder M et al (1997) Generalized CNS disease and massive GM1-ganglioside accumulation in mice defective in lysosomal acid beta-galactosidase. Hum Mol Genet 6:205-11.

Hammer MB, Eleuch-Fayache G, Schottlaender LV et al. (2013) Mutations in GBA2 cause autosomal-recessive cerebellar ataxia with spasticity. Am J Hum Genet 92: 245-251.

Hanein S, Perrault I, Gerber S et al (2004) Leber congenital amaurosis: comprehensive survey of the genetic heterogeneity, refinement of the clinical definition, and genotypephenotype correlations as a strategy for molecular diagnosis. Hum Mutat 23:306-317

Happle R. (1979) X-linked dominant chondrodysplasia punctata. Review of literature and report of a case. Hum Genet 53:65-73.

Harding AE (1983) Classification of the Hereditary Ataxias and Paraplegias. Lancet 1:11511155.

Harlalka GV, Lehman A, Chioza B et al (2013) Mutations in B4GALNT1 (GM2 synthase) underlie a new disorder of ganglioside biosynthesis. Brain 136:3618-24.

Hartig MB, luso A, Haack $T$ et al (2011). Absence of an orphan mitochondrial protein, 
c19orf12, causes a distinct clinical subtype of neurodegeneration with brain iron accumulation. Am J Hum Genet 89:543-50.

He M, Kratz LE, Joshua J. (2011) Mutations in the human SC4MOL gene encoding a methyl sterol oxidase cause psoriasiform dermatitis, microcephaly, and developmental delay. $\mathrm{J}$ Clin Invest 121:976-984

Hoopes RR Jr, Shrimpton AE, Knohl SJ, et al (2005) Dent Disease with mutations in OCRL1. Am J Hum Genet 76: 260-267

Huber C, Faqeih EA, Bartholdi D et al (2013) Exome sequencing identifies INPPL1 mutations as a cause of opsismodysplasia. Am J Hum Genet 92:144-9.

Huppke P, Brendel C, Kalscheuer V et al (2012) Mutations in SLC33A1 cause a lethal autosomal-recessive disorder with congenital cataracts, hearing loss, and low serum copper and ceruloplasmin. Am J Hum Genet. 90:61-8.

Houten SM, Frenkkel J, Waterham HR (2003) Isoprenoid biosynthesis in hereditary periodic fever syndrome and inflammation. Cell Mol Life Sci 60:1118-1134

Israeli S, Khamaysi Z, Fuchs-Telem D (2011) A Mutation in LIPN, Encoding Epidermal Lipase N, Causes a Late-Onset Form of Autosomal-Recessive Congenital Ichthyosis. Am J Hum Genet 88: 482-487.

Jakobs BS, van den Heuvel LP, Smeets RJ et al (2013) A novel mutation in COQ2 leading to fatal infantile multisystem disease. J Neurol Sci 326:24-28

Jobard F,Lefevre C,Karaduman C et al (2002) Lipoxygenase-3 (ALOXE3) and 12(R)lipoxygenase (ALOX12B) are mutated in non-bullous congenital ichthyosiform erythroderma (NCIE) linked to chromosome 17p13.1. Hum Mol Genet $11: 107-113$

Kaneko K, Kuroda H, Izumi R et al (2014) A novel mutation in PNPLA2 causes neutral lipid storage disease with myopathy and triglyceride deposit cardiomyovasculopathy: a case report and literature review. Neuromuscul Disord 24:634-41.

Kapina V, Sedel F, Truffert A, et al (2010) Relapsing rhabdomyolysis due to peroxisomal alpha-methylacyl-coa racemase deficiency. Neurology 75:1300-2.

Kapusta L, Zucker N, Frenckel G et al (2012) From discrete dilated cardiomyopathy to successful cardiac transplantation in congenital disorders of glycosylation due to dolichol kinase deficiency (DK1-CDG). Heart Fail Rev 18:187-96.

Keppler-Noreuil KM, Sapp JC,Marjorie MJ et al (2014) Clinical Delineation and Natural History of the PIK3CA-Related Overgrowth Spectrum. Am J Med Genet 1713-1733

Köhn L, Kadzhaev K, Burstedt MSI et al (2007) Mutation in the PYK2-binding domain of PITPNM3 causes autosomal dominant cone dystrophy (CORD5) in two Swedish families. Eur J Hum Genet 15:664-671.

Krawitz PM, Murakami Y, Hecht J, et al (2012) Mutations in PIGO, a member of the GPIanchor-synthesis pathway, cause hyperphosphatasia with mental retardation.Am $\mathrm{J}$ Hum Genet. 91:146-51.

Krawitz PM, Murakami Y, Rieß A et al (2013) PGAP2 mutations, affecting the GPI-anchor- 
synthesis pathway, cause hyperphosphatasia with mental retardation syndrome. Am J Hum Genet 92:584-9

Kruer MC, Paisán-Ruiz C, Boddaert N et al (2010) Defective FA2H leads to a novel form of neurodegeneration with brain iron accumulation (NBIA). Ann Neurol 68:611-8.

Kurian MA, Hayflick SJ (2013) Pantothenate kinase-associated neurodegeneration (PKAN) and PLA2G6-associated neurodegeneration (PLAN): review of two major neurodegeneration with brain iron accumulation (NBIA) phenotypes. Int Rev Neurobiol 110:49-71.

Lagier-Tourenne C, Tazir M, López LC et al (2008) ADCK3, an ancestral kinase, is mutated in a form of recessive ataxia associated with coenzyme Q10 deficiency. Am J Hum Genet 82:661-672

Lefeber DJ, de Brouwer APM, Morava E et al (2011) Autosomal recessive dilated cardiomyopathy due to DOLK mutations results from abnormal dystroglycan $\mathrm{O}$ mannosylation. PLoS Genet 7: e1002427.

Lefèvre C, Jobard F, Caux F et al (2001) Mutations in CGI-58, the gene encoding a new protein of the esterase/lipase/thioesterase subfamily, in Chanarin-Dorfman syndrome. Am J Hum Genet 69:1002-12.

Lefévre C, Audebert S, Jobard F et al (2003) Mutations in the transporter ABCA12 are associated with lamellar ichthyosis type 2. Hum Mol Genet 12:2369-78.

Lefèvre C, Bouadjar B, Ferrand V et al (2006 Mutations in a new cytochrome P450 gene in lamellar ichthyosis type 3. Hum Mol Genet. 15:767-76.

Lemaire M, Frémeaux-Bacchi $V$, Schaefer $F$ et al (2013), Recessive mutations in DGKE cause atypical hemolytic-uremic syndrome. Nat Genet 45:531-6.

Levi S, Finazzi D (2014) Neurodegeneration with brain iron accumulation: update on pathogenic mechanisms. Front Pharmacol 5:99

Liguori R, Giannoccaro MP, Arnoldi A et al (2014) Impairment of brain and muscle energy metabolism detected by magnetic resonance spectroscopy in hereditary spastic paraparesis type 28 patients with DDHD1 mutations. J Neurol Jul 3 [Epub ahead of print]

Lindhurst MJ, Parker VER, Payne F et al (2012). Mosaic overgrowth with fibroadipose hyperplasia is caused by somatic activating mutations in PIK3CA. Nat Genet 44:928933.

Lo Giudice T, Lombardi F, Santorelli FM et al (2014) Hereditary spastic paraplegia: Clinicalgenetic characteristics and evolving molecular mechanisms. Exp Neurol 2014 Jun 20 [Epub ahead of print]

Mackay DS, Borman AD, Sui R (2013) Screening of a large cohort of leber congenital amaurosis and retinitis pigmentosa patients identifies novel LCA5 mutations and new genotype-phenotype correlations. Hum Mutat 34:1537-46.

Martin E, Schüle R, Smets K et al (2013) Loss of function of glucocerebrosidase GBA2 is responsible for motor neuron defects in hereditary spastic paraplegia. Am J Hum Genet 92:238-44. 
Mayr JA, Haack TB, Graf E et al (2012) Lack of the mitochondrial protein acylglycerol kinase causes Sengers syndrome. Am J Hum Genet 90:314-20.

Méneret A, Wiame E, Marelli C et al (2012) A serine synthesis defect presenting with a Charcot-Marie-Tooth-like polyneuropathy. Arch Neurol 69:908-11.

Michot C, Hubert L, Brivet M et al (2010) LPIN1 gene mutations: a major cause of severe rhabdomyolysis in early childhood. Hum Mutat 31:E1564-73.

Mignot C, Doummar D, Maire I et al (2006) Type 2 Gaucher disease: 15 new cases and review of the literature. Brain Dev. 2006 Jan;28(1):39-48

Millón MB, Delgado MA, Azar NB et al (2011) Two Argentinean Siblings with CDG-Ix: A Novel Type of Congenital Disorder of Glycosylation? JIMD Rep;1:65-72.

Mitsuhashi S, Ohkuma A, Talim B et al (2011) A congenital muscular dystrophy with mitochondrial structural abnormalities caused by defective de novo phosphatidylcholine biosynthesis. Am J Hum Genet 88:845-51.

Molday RS, Zhang K, Quazi F (2009) The role of the photoreceptor ABC transporter ABCA4 in lipid transport and Stargardt macular degeneration. Biochim Biophys Acta 1791:573583

Molday RS and Zhang K (2010) Defective lipid transport and biosynthesis in recessive and dominant Stargardt macular degeneration. Prog Lipid Res 49:476-492

Morgan NV, Westaway SK, Morton JE, et al (2006). PLA2G6, encoding a phospholipase A2, is mutated in neurodegenerative disorders with high brain iron. Nat Genet. 38:752-4

Muhammad E, Reish O, Ohno Y et al (2013) Congenital myopathy is caused by mutation of HACD1. Hum Mol Genet 22:5229-36

Murphy SM, Ernst D, Wei Y, et al. (2013) Hereditary sensory and autonomic neuropathy type 1 (HSANI) caused by a novel mutation in SPTLC2. Neurology 80(23): 2106-2111.

Nakano M, Kelly EJ, Wiek C et al (2012) CYP4V2 in Bietti's crystalline dystrophy: ocular localization, metabolism of $\omega$-3-polyunsaturated fatty acids, and functional deficit of the p.H331P variant. Mol Pharmacol 82:679-86

Narkis G, Ofir R, Landau D et al (2007) Lethal contractural syndrome type 3 (LCCS3) is caused by a mutation in PIP5K1C, which encodes PIPKI gamma of the phosphatidylinositol pathway. Am J Hum Genet 81: 530-539, 2007

Ng BG, Hackmann K, Jones MA et al (2012) Mutations in the glycosylphosphatidylinositol gene PIGL cause CHIME syndrome. Am J Hum Genet 90:685-8.

Nishiguchi KM, Avila-Fernandez A, van Huet RA et al (2014) Exome Sequencing Extends the Phenotypic Spectrum for ABHD12 Mutations: From Syndromic to Nonsyndromic Retinal Degeneration. Ophthalmology. 31. pii: S 0161-6420 (14) 00138-9. doi: 10.1016/ j.ophtha.2014.02.008. [Epub ahead of print]

Novarino G, Fenstermaker AG, Zaki MS et al (2014) Exome sequencing links corticospinal motor neuron disease to common neurodegenerative disorders. Science 343:506-11 
Odievre MH, Sevin C, Laurent J, et al (2002) Long-chain 3-hydroxyacylCoA dehydrogenase deficiency: a new case presenting with liver dysfunction, cholestasis and fibrosis. Acta Pediatr $91: 719-722$.

Oji V, Tadini G, Akiyama M, et al (2010) Revised nomenclature and classification of inherited ichthyoses: results of the First Ichthyosis Consensus Conference in Sorèze 2009. J Am Acad Dermatol 63:607-41.

Ombrello MJ, Remmers EF, Sun G et al (2012) Cold urticaria, immunodeficiency, and autoimmunity related to PLCG2 deletions. New Eng J Med 366: 330-338.

Olpin SE, Clark S, Andresen BS et al (2005) Biochemical, clinical and molecular findings in LCHAD and general mitochondrial trifunctional protein deficiency. $J$ Inherit Metab Dis 28:533-44.

Ozaltin F, Li B, Rauhauser A et al (2013) DGKE variants cause a glomerular microangiopathy that mimics membranoproliferative GN. J Am Soc Nephrol 24:377-84

Pang J, Kiyosawa M, Seko Y et al (2001) Clinicopathological report of retinitis pigmentosa with vitamin $\mathrm{E}$ deficiency caused by mutation of the alpha-tocopherol transfer protein gene. Jpn J Ophthalmol 45:672-6

Patterson MC, Hendriksz CJ, Walterfang M et al (2012) Recommendations for the diagnosis and management of Niemann-Pick disease type C: an update. Mol Genet Metab 106:330-44.

Payne F, Lim K, Girousse A et al (2014) Mutations disrupting the Kennedy phosphatidylcholine pathway in humans with congenital lipodystrophy and fatty liver disease. Proc Natl Acad Sci U S A. 111:8901-6.

Perrault I, Hanein S, Gerber S et al (2004) Retinal dehydrogenase 12 (RDH12) mutations in Leber congenital amaurosis. Am J Hum Genet 75:639-646.

Poll-The BT Saudubray JM, Ogier H et al (1987) Infantile Refsum disease: an inherited peroxisomal disorder. Comparison with Zellweger syndrome and neonatal adrenoleukodystrophy. Eur J Pediatr 146:477-483

Poll-The BT, Billette de Villemeur T, Abitol M et al (1992) Metabolic pigmentary retinopathies: diagnosis and therapeutic attempts. Eur J Pediatr 151:2-11.

Poll-The BT, Maillette De Buy LJ ,Wenniger-Prick LJ et al (2003) The eye as a window to inborn errors of metabolism. J Inherit Metab Dis 26: 229-244

Rainier S, Bui M, Mark E et al (2008) Neuropathy target esterase gene mutations cause motor neuron disease. Am J Hum Genet 82:780-785.

Rattner A, Sun H, Nathans J (1999) Molecular genetics of human retinal disease. Ann Rev Genet 33: 89-131.

Rader DJ, Brewer HB (1993) Abetalipoproteinemia: New insights into lipoprotein assembly and vitamin $E$ metabolism for a rare genetic disease. JAMA $270: 865-869$ 
Radner FPW, Marrakchi S , Kirchmeier P et al (2013) Mutations in CERS3 Cause Autosomal Recessive Congenital Ichthyosis in Humans. PLoS Genet 9:e1003536

Retnet Retinal information network https://sph.uth.edu/retnet/

Rizzo WB (2014) Fatty aldehyde and fatty alcohol metabolism: Review and importance for epidermal structure and function. Biochim Biophys Acta 1841:377-389.

Rogers GR, Markova NG, De Laurenzi V et al (1997) Genomic organization and expression of the human fatty aldehyde dehydrogenase gene (FALDH). Genomics 39: 127-135

Rotthier A, Auer-Grumbach M, Janssens K et al (2010) Mutations in the SPTLC2 subunit of serine palmitoyltransferase cause hereditary sensory and autonomic neuropathy type I. Am J Hum Genet 87: 513-522.

Rotig A, Appelkvist EL, Geromel V et al (2000) Quinone-responsive multiple respiratorychain dysfunction due to widespread coenzyme Q10 deficiency. Lancet 356:391-395

Salviati L, Sacconi S, Murer L et al (2005) Infantile encephalomyopathy and nephropathy with CoQ10 deficiency: a CoQ10-responsive condition. Neurology 65:606-608

Salviati L, Trevisson E, Rodriguez Hernandez MA et al (2012) Haploinsufficiency of COQ4 causes coenzyme Q10 deficiency. J Med Genet 49:187-191

Sarig O, Goldsher D, Nousbeck J et al (2013) Infantile mitochondrial hepatopathy is a cardinal feature of MEGDEL syndrome (3-methylglutaconic aciduria type IV with sensorineural deafness, encephalopathy and Leigh-like syndrome) caused by novel mutations in SERAC1. Am J Med Genet A 161:2204-15.

Saudubray J, Martin D, De Lonlay P, et al (1999) Recognition and management of fatty acid oxidation defects : a series of 107 patients. J Inher Metab Dis 22 : 488-502.

Saudubray JM (2012) Clinical approach to inborn errors of metabolism in paediatrics. In Saudubray ,van den Berghe, Walter eds: Inborn metabolic diseases Springer Verlag Berlin Heidelberg 5th Edt, 20121 : pp 4-54.

Schenk B, Imbach T, Frank CG et al (2001) MPDU1 mutations underlie a novel human congenital disorder of glycosylation, designated type If. J Clin Invest 108:1687-95.

Schneider SA, Dusek P, Hardy J et al (2013) Genetics and Pathophysiology of Neurodegeneration with Brain Iron Accumulation (NBIA). Curr Neuropharmacol 11:59-79

Schuurs-Hoeijmakersa JH, Geraghty MT, Kamsteeg EJ et al (2012) Mutations in DDHD2, encoding an intracellular phospholipase $A(1)$, cause a recessive form of complex hereditary spastic paraplegia. Am J Hum Genet 91:1073-81.

Seeliger MW , Biesalski HK, Wissinger B et al (1999) Phenotype in retinol deficiency due to a hereditary defect in retinol binding protein synthesis. J Invest Ophthalmol Vis Sci 40 :311.

Sengers RC, Trijbels JM, Willems JL, et al (1975) Congenital cataract and mitochondrial myopathy of skeletal and heart muscle associated with lactic acidosis after exercise. $\mathrm{J}$ Pediatr 86:873-80. 
Sergouniotis PI, Davidson AE, Mackay DS et al (2011) Biallelic mutations in PLA2G5, encoding group $\mathrm{V}$ phospholipase $\mathrm{A}_{2}$, cause benign fleck retina. Am J Hum Genet 89:782791.

Setchell KD, Heubi JE, Bove KE et al (2003) Liver disease caused by failure to racemize trihydroxycholestanoic acid: gene mutation and effect of bile acid therapy. Gastroenterology 124:217-232

Setchell KDR, Schwarz M, O'Connell NC et al (1998) Identification of a new inborn error in bile acid synthesis: mutation of the oxysterol $7 \alpha$-hydroxylase gene causes severe neonatal liver disease. J Clin Invest 102:1690-170

Shaheen R, Rahbeeni Z, Alhashem A et al (2014) Neu-Laxova Syndrome, an Inborn Error of Serine Metabolism, Is Caused by Mutations in PHGDH. Am J Hum Genet. 94:898-904

Siemiatkowska AM, van den Born LI, van Hagen MP et al (2013) Mutations in the mevalonate kinase $(M V K)$ gene cause nonsyndromic retinitis pigmentosa. Ophthalmology 120:2697-2705.

Simpson MA, Cross H, Proukakis et al (2004) Infantile-onset symptomatic epilepsy syndrome caused by a homozygous loss-of-function mutation of GM3 synthase. Nature Genet 36: 1225-1229

Siriwardena K, Mackay N, Levandovskiy V et al (2013) Mitochondrial citrate synthase crystals: novel finding in Sengers syndrome caused by acylglycerol kinase (AGK) mutations.Mol Genet Metab 108: 40-50.

Skjeldal $\mathrm{OH}$, Stokke $\mathrm{O}$, Refsum $\mathrm{S}$ et al Clinical and biochemical heterogeneity in conditions with phytanic acid accumulation. J Neurol Sci 77:87-96.

Smith EH, Gavrilov DK, Oglesbee D et al (2010) An adult onset case of alpha-methyl-acylCoA racemase deficiency. J Inherit Metab Dis 33 Suppl 3:S349-53.

Sousa SB, Jenkins D, Chanudet E et al (2014) Gain-of-function mutations in the phosphatidylserine synthase 1 (PTDSS1) gene cause Lenz-Majewski syndrome. Nature Genet 46 : 70-77.

Sparrow JR, Wu Y, Zhou J (2010) Phospholipids meets all-trans-retinal : the making of RPE bisretinoids. J Lipid Res 51:247-261.

Spiekerkoetter U, Khuchua Z, Yue Z et al. (2004) General mitochondrial trifunctional protein (TFP) deficiency as a result of either alpha- or beta-subunit mutations exhibits similar phenotypes because mutations in either subunit alter TFP complex expression and subunit turnover. Pediatr Res 55:190-196

Steinberg SJ, Moser AB, BA, Raymond GV. X-Linked Adrenoleukodystrophy. In: Gene Reviews. http://www.ncbi.nlm.nih.gov/books/NBK1315/Initial Posting: March 26, 1999; Last Update: April 19, 2012.

Stirnemann J, Vigan M, Hamroun D et al (2012) The French Gaucher's disease registry: clinical characteristics, complications and treatment of 562 patients. Orphanet J Rare Dis. 9;7:77. 
Suchy SF, Nussbaum RL (2002) The deficiency of PIP2 5-phosphatase in Lowe syndrome affects actin polymerization.Am J Hum Genet 71: 1420-1427

Suh BC, Hong YB, Nakhro K, et al (2013) Early-onset severe hereditary sensory and autonomic neuropathy type 1 with S331F SPTLC1 mutation. Mol Med Rep 9: 481-486.

Suh BC, Hong YB, Nakhro K, et al (2014) Early-onset severe hereditary sensory and autonomic neuropathy type 1 with S331F SPTLC1 mutation.Mol Med Rep. 9:481-6.

Synofzik M, Gonzalez MA, Lourenco CM et al (2014) PNPLA6 mutations cause BoucherNeuhauser and Gordon Holmes syndromes as part of a broad neurodegenerative spectrum. Brain 137:69-77.

Tesson C, Nawara M, Salih MA et al (2012). Alteration of fatty-acid-metabolizing enzymes affects mitochondrial form and function in hereditary spastic paraplegia. Am J Hum Genet 91:1051-64.

Thauvin-Robinet C, Auclair M, Duplomb L (2013) PIK3R1 mutations cause syndromic insulin resistance with lipoatrophy. Am J Hum Genet 93:141-9.

Thompson DA, Li Y, McHenry CL et al (2001) Mutations in the gene encoding lecithin retinol acyltransferase are associated with early-onset severe retinal dystrophy. Nat Genet 128:123-124.

Tsaousidou MK, Ouahchi K, Warner TT et al (2008) Sequence alterations within CYP7B1 implicate defective cholesterol homeostasis in motor-neuron degeneration. Am J Hum Genet 82:510-515

Vaccaro AM, Motta M, Tatti M et al (2010) Saposin C mutations in Gaucher disease patients resulting in lysosomal lipid accumulation, saposin $C$ deficiency, but normal prosaposin processing and sorting. Hum Mol Genet 19:2987-97.

Vanier MT (2010) Niemann-Pick type C. Orphanet J Rare Dis ,5:16

Vanier MT, Caillaud C (2012) Disorders of sphingolipid metabolism and neuronal ceroid lipofucinoses. In: Inborn Metabolic Diseases, Saudubray, Van den Berghe, Walter Edt, $5^{\text {th }}$ Edd, Springer-Verlag Berlin Heidelberg Edt. Pp 555:574

Vanier MT (2013) Niemann-Pick diseases. Handb Clin Neurol 113:1717-21.

Van Veldhoven PP, Meyhi E, Squires RH et al (2001) Fibroblast studies documenting a case of peroxisomal 2-methylacyl-CoA racemase deficiency: possible link between racemase deficiency and malabsorption and vitamin K deficiency. Eur J Clin Invest 31:714-722

Wanders RJA, Waterham HR, Leroy BP (2010) Refsum Disease. In: Pagon RA, Adam MP, Ardinger HH, Bird TD, Dolan CR, Fong CT, Smith RJH, Stephens K, editors. Source: GeneReviews ${ }^{\circledR}$ [Internet]. Seattle (WA): University of Washington, Seattle; 1993-2014. 2006 Mar 20 [updated 2010 Apr 22].

Wanders RJA, Komen J, Ferdinandusse S (2011) Phytanic acid metabolism in health and disease. Biochim Biophys Acta 1811 : 498-507

Waterham HR (2006) Defects of cholesterol biosynthesis. FEBS Lett. 580:5442-9. 
Waterham HR, Ebberink MS (2012 a) Genetics and molecular basis of human peroxisome biogenesis disorders. Biochim Biophys Acta 1822:1430-41.

Waterham HR and Clayton P (2012 b ) Disorders of cholesterol synthesis. In Saudubray van den Berghe, Walter edt : Inborn metabolic diseases Springer Verlag Berlin Heidelberg edt $5^{\text {th }}$ eds, pp 463-471

Willemsen MA, ljlst L, Steijlen PM et al (2001) Clinical, biochemical and molecular genetic characteristics of 19 patients with the Sjogren-Larsson syndrome. Brain 124:1426-1437

Wolfe LA, Morava E, He M, Vockley J, Gibson KM. (2012.) Heritable disorders in the metabolism of the dolichols: A bridge from sterol biosynthesis to molecular glycosylation. Am J Med Genet Part C Semin Med Genet 9999:1-7.

Wortmann SB, Vaz FM, Gardeitchik T et al (2012) Mutations in the phospholipid remodeling gene SERAC1 impair mitochondrial function and intracellular cholesterol trafficking and cause dystonia and deafness. Nat Genet 44:797-802.

Xie YA, Lee W, Cai $C$ et al (2014) New syndrome with retinitis pigmentosa is caused by nonsense mutations in retinol dehydrogenase RDH11. Hum Mol Genet Jun 10. pii: ddu291. [Epub ahead of print]

Yamamoto H, Simon A, Eriksson U et al (1999). Mutations in the gene encoding 11-cis retinol dehydrogenase cause delayed dark adaptation and fundus albipunctatus. Nat Genet 22:188-191

Yamamoto GL, Wagner ARB, Almeida TF, et al, (2014), Mutations in PCYT1A Cause Spondylometaphyseal Dysplasia with Cone-Rod Dystrophy. Am J Hum Genet 94, 113119.

Zeharia A, Shaag A, Houtkooper RH, et al (2008) Mutations in LPIN1 cause recurrent acute myoglobinuria in childhood. Am J Hum Genet 83:489-94.

Zelinger L, Banin E, Obolensky A et al (2011) A missense mutation in DHDDS, encoding dehydrodolichyl diphosphate synthase, is associated with autosomal-recessive retinitis pigmentosa in Ashkenazi Jews. Am J Hum Genet 88:207-215.

Zhang K, Kniazeva M, Hutchinson $\mathrm{A}$ et al (1999) The $A B C R$ gene in recessive and dominant Stargardt diseases: a genetic pathway in macular degeneration. Genomics 60:234-237

Zhang K, Kniazeva M, Han M et al (2001) A 5-bp deletion in ELOVL4 is associated with two related forms of autosomal dominant macular dystrophy. Nat Genet 27:89-93

Zöller I, Meixner M, Hartmann D et al (2008) Absence of 2-hydroxylated sphingolipids is compatible with normal neural development but causes late-onset axon and myelin sheath degeneration. J Neurosci 28: 9741-9754.

Züchner S, Dallman J, Wen R et al (2011), Whole-exome sequencing links a variant in DHDDS to retinitis pigmentosa. Am J Hum Genet 88:201-206 


\begin{tabular}{|c|c|c|c|c|c|}
\hline $\begin{array}{l}\text { PREDOMINANT } \\
\text { NEUROLOGICAL } \\
\text { SYNDROME }\end{array}$ & $\begin{array}{l}\text { AGE AT } \\
\text { ONSET }\end{array}$ & MAJOR SYMPTOMS and BRAIN IMAGE & $\begin{array}{l}\text { DEFECTIVE } \\
\text { ENZYME }\end{array}$ & $\begin{array}{c}\text { DEFECTIVE } \\
\text { GENE } \\
\text { (Inheritance) }\end{array}$ & $\begin{array}{l}\text { BIBLIOGRAPHIC } \\
\text { REFERENCES }\end{array}$ \\
\hline $\begin{array}{l}\text { HEREDITARY } \\
\text { SPASTIC PARAPARESIS } \\
\text { (SP) }\end{array}$ & $\begin{array}{l}\text { Infantile }<2 \\
\text { years }\end{array}$ & $\begin{array}{l}\text { HSP related to “INAD” phenotype: truncal hypotonia, } \\
\text { psychomotor deterioration, cerebellar ataxia, early onset optic } \\
\text { atrophy, abnormal EEG pattern (fast rhythms). Brain MRI: } \\
\text { cerebellar atrophy, high intensity cerebellar cortex; } \\
\text { hypointensities pallidum and SN. } \\
\text { HSP with ichthyosis: } \\
\text { - Sjögren-Larsson syndrome: mild to moderate DD, } \\
\text { retinopathy, pseudobulbar dysarthria. Brain MRI: Delayed } \\
\text { myelination and abnormal lipid peak on MRS (white matter) } \\
\text {-HSP with ichthyosis resembling Sjögren-Larsson syndrome. } \\
\text { Severe DD, refractory seizures and cataracts. } \\
\text { HSP with variable degrees of cognitive involvement and brain } \\
\text { MRI findings: } \\
\text { - SPG56: “Pure” HSP or associated with variable degree of DD } \\
\text { and infraclinic axonal neuropathy. Brain MRI: normal or thin CC } \\
\text { with basal ganglia calcifications. } \\
\text {-HSP with CC agenesis and normal cognition. Brain MRI: CC } \\
\text { agenesis, vermis hypoplasia and defective myelination (1 early- } \\
\text { onset case described; first symptoms at } 9 \text { months of life) } \\
\text { HSP with severe spasticity and severe DD, SPG54. Brain MRI: } \\
\text { PVWMH, thin CC. Abnormal lipid peak on MRS (basal ganglia) }\end{array}$ & $\begin{array}{l}\text { Calcium } \\
\text { independent } \\
\text { phospholipase A2y } \\
\text { Fatty acid aldehyde } \\
\text { dehydrogenase } \\
\text { Fatty acid elongase } \\
\text { ELOVL4 } \\
\text { Cytochrome P450 } \\
\text { hydroxylase } \\
\text { GPI-Anchor } \\
\text { synthesis pathway } \\
\text { Phospholipase A1 }\end{array}$ & $\begin{array}{l}\text { ELOVL4 (AR) } \\
\text { CYP2U1 (AR) }\end{array}$ & $\begin{array}{l}\text { Aldamesh et al, } \\
2011 \\
\text { Tesson et al, } 2012\end{array}$ \\
\hline
\end{tabular}




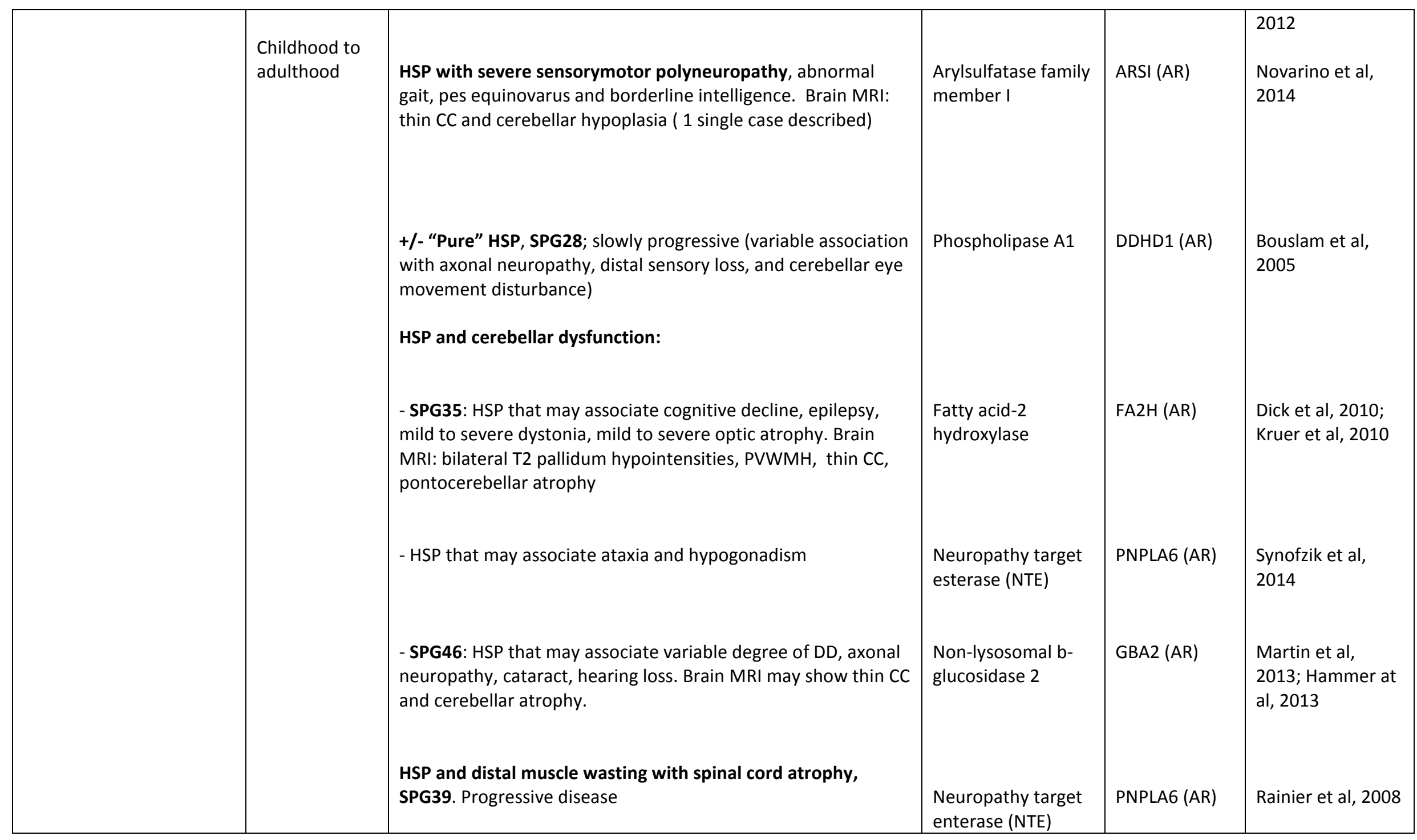









\begin{tabular}{|c|c|c|c|c|c|}
\hline & & $\begin{array}{l}\text { Childhood onset HSP and DD and later dystonia, dysarthria and } \\
\text { spastic-dystonic tetraparesis Brain MRI: T2 hyperintensity and } \\
\text { swelling of both caudate nuclei and putamen, mild } \\
\text { hyperintensity of both thalami. T2 hypointensity of the } \\
\text { pallidum may appear later. }\end{array}$ & $\begin{array}{l}\text { CoA synthase } \\
\text { deficiency }\end{array}$ & COASY (AR) & Dusi et al, 2014 \\
\hline ATAXIA & $\begin{array}{l}\text { Infantile to } \\
\text { adolescence } \\
\text { Childhood to } \\
\text { adulthood }\end{array}$ & $\begin{array}{l}\text { ARCA with hypogonadotropic hypogonadism: } \\
\text { - Boucher-Neuhäuser syndrome (MIM 215470), with } \\
\text { chorioretinal dystrophy. } \\
\text { - Gordon Holmes syndrome (MIM 215470), with brisk reflexes. } \\
\text { Sensory motor axonal neuropathy may be present but not } \\
\text { constant. Brain MRI: cerebellar atrophy. Pons and pituitary may } \\
\text { be atrophic. } \\
\text { ARCA +/- other manifestations such as migraines, seizures, } \\
\text { psychiatric symptoms } \\
\text { Ataxia and gait impairment may be present as an associated } \\
\text { sign in diverse disorders that cause HSP or NBIA as } \\
\text { predominant phenotypes. }\end{array}$ & $\begin{array}{l}\text { Neuropathy target } \\
\text { enterase (NTE) } \\
\text { Coenzyme Q10 } \\
\text { deficiency }\end{array}$ & $\begin{array}{l}\text { COQ8-ADCK3 } \\
\text { (AR) }\end{array}$ & $\begin{array}{l}\text { Lagier-Tourenne } \\
\text { 2008; Blumkin et } \\
\text { al } 2014\end{array}$ \\
\hline $\begin{array}{l}\text { MOVEMENT } \\
\text { DISORDERS }\end{array}$ & Infantile & $\begin{array}{l}\text { Leigh-like syndrome due to MEGDEL (3-methylglutaconic } \\
\text { aciduria with deafness, encephalopathy and Leigh-like) } \\
\text { syndrome. Neonatal hypoglycemia followed by transient } \\
\text { hepatic failure. By age } 2 \text { years progressive deafness, dystonia, } \\
\text { spasticity and psychomotor stagnation. Brain MRI: Leigh-like } \\
\text { bilateral basal ganglia involvement } \\
\text { Leigh syndrome with multisystem involvement (nephropathy } \\
\text { and cardiomyopathy) }\end{array}$ & $\begin{array}{l}\text { Protein localized at } \\
\text { (MAM) } \\
\text { mitochondrial } \\
\text { associated proteins } \\
\text { Coenzyme Q } \\
\text { deficiency }\end{array}$ & $\begin{array}{l}\text { SERAC1 (AR) } \\
\text { COQ1-PDSS2 } \\
\text { (AR) }\end{array}$ & $\begin{array}{l}\text { Wortmann et al, } \\
2012\end{array}$ \\
\hline
\end{tabular}




\begin{tabular}{|c|c|c|c|c|c|}
\hline & $\begin{array}{l}\text { Adolescence } \\
\text { to adulthood }\end{array}$ & $\begin{array}{l}\text { Choreoathetosis associated with early onset epilepsy, DD, } \\
\text { optic atrophy and hyperpigmented lesions. } \\
\text { Dystonia-Parkinsonism (PARK14). Dyskinesia associated with } \\
\text { tremor including a pill-rolling rest component, rigidity and } \\
\text { severe bradykinesia with a good response to L-Dopa; Levy body } \\
\text { pathology. Psychiatric symptoms may precede motor signs. } \\
\text { Brain MRI: may be normal or show cortical atrophy +/- white } \\
\text { matter changes. } \\
\text { Dystonia-Parkinsonism may be present in any cause of NBIA } \\
\text { syndrome. } \\
\text { Dystonia may be present in complex forms of HSP, especially } \\
\text { SPG26 (B4GALNT1), SPG35 (FA2H) and SPG56 (CYP2U1). } \\
\text { Parkinsonism may appear very often at late stages of } \\
\text { neurodegenerative diseases regardless of the molecular origin }\end{array}$ & $\begin{array}{l}\text { Lactosylceramide } \\
\alpha-2,3 \text { sialyl } \\
\text { transferase (GM3 } \\
\text { synthase) } \\
\text { Calcium } \\
\text { independent } \\
\text { phospholipase A2 } \gamma\end{array}$ & PLA2G6 (AR) & $\begin{array}{l}\text { Simpson et al, } \\
\text { 2004; Fragaki et } \\
\text { al, } 2013 \\
\text { Kurian and } \\
\text { Hayflick, } 2013\end{array}$ \\
\hline $\begin{array}{l}\text { COMPLEX OR } \\
\text { SYNDROMIC } \\
\text { DEVELOPMENTAL } \\
\text { DELAY/ INTELECTUAL } \\
\text { DISABILITY }\end{array}$ & Infantile & $\begin{array}{l}\text { DD and/or ID may be present as an associated sign in diverse } \\
\text { disorders that cause HSP, NBIA or movement disorders as } \\
\text { predominant phenotypes. } \\
\text { HPMRS: Hyperphosphatasia and Mental Retardation } \\
\text { Syndrome. Global developmental delay with marked } \\
\text { involvement of expressive language. Coarse facial features. } \\
\text { Epilepsy may be present. Anorectal abnormalities and other } \\
\text { malformations may be present. In PIGW (1 case described) the }\end{array}$ & $\begin{array}{l}\text { Defects in the GPI- } \\
\text { anchor- } \\
\text { biosynthesis } \\
\text { pathway }\end{array}$ & $\begin{array}{l}\text { PGAP2, } \\
\text { PGAP3, PIGV } \\
\text { PIGO, PIGW }\end{array}$ & $\begin{array}{l}\text { Krawitz et al, } \\
2012,2013 \\
\text { Chiyonobou et al, } \\
2013\end{array}$ \\
\hline
\end{tabular}




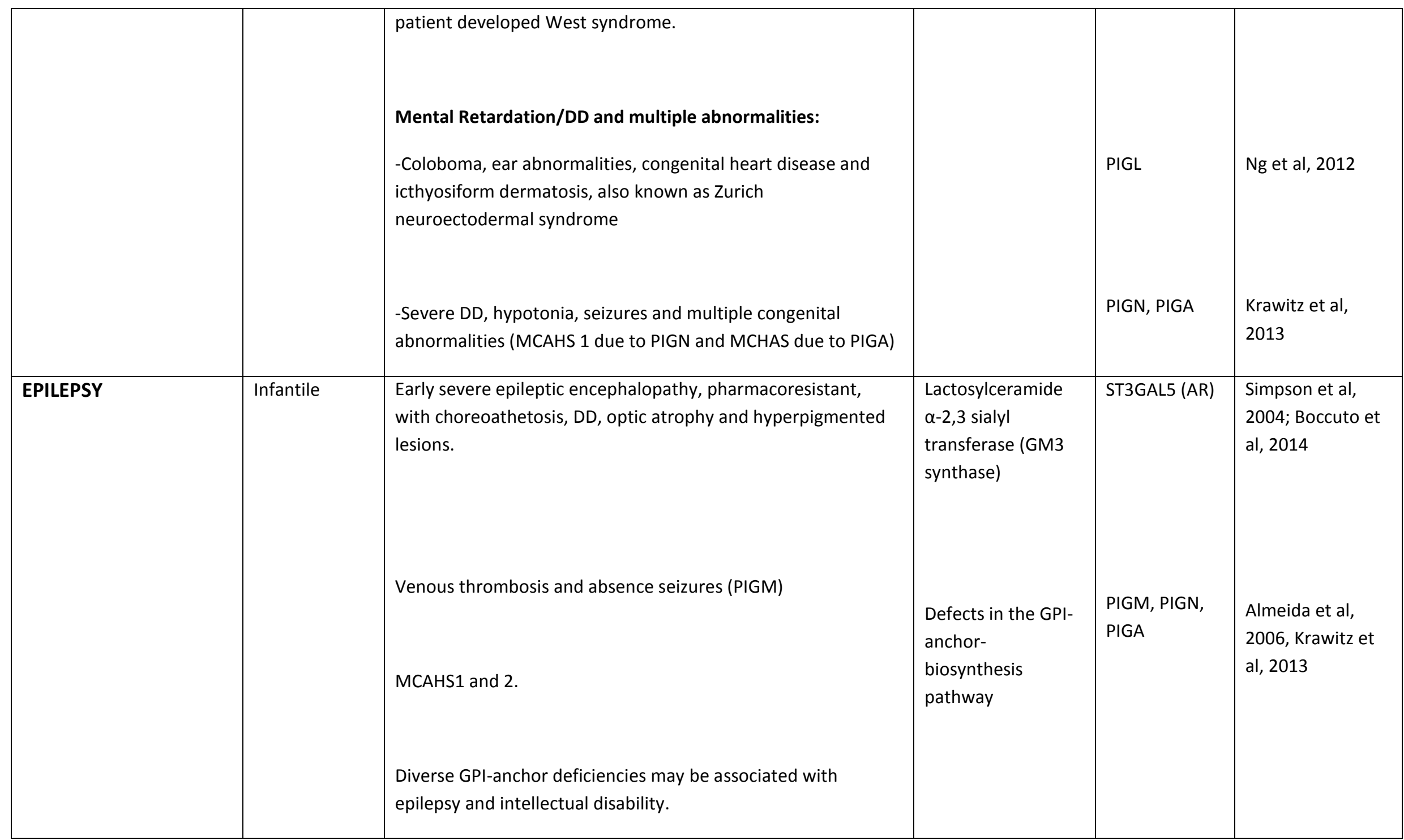




\begin{tabular}{|l|l|l|l|l|}
\hline & & $\begin{array}{l}\text { Early refractory seizures may appear also in PLA2G6, FA2H and } \\
\text { ELOVL4 mutations }\end{array}$ & \\
\hline
\end{tabular}

\section{Table 1 Neurological presentations: central nervous system involvement}

\section{Abbreviations:}

AR: autosomal recessive; ARCA: autosomal recessive cerebellar ataxia. CC: corpus callosum. DD: Developmental delay; ELOVL4: elongase/elongation of very long chain fatty acids deficiency; FA2H: Fatty acid 2-hydroxylase deficiency. FALDH: Fatty aldehyde dehydrogenase deficiency; GM3S: gangliosidosis type 3 synthase deficiency; GP: globus pallidum; GPI: glycosylphosphatidylinositol. HPMRS: Hyperphosphatasia and Mental Retardation Syndrome. HSP: hereditary spastic paraparesis; ID: Intellectual disability; iPLA1: intracellular phospholipase A1. INAD: infantile neuroaxonal dystrophy; LeukoD: leukodystrophy; MCAHS: multiple congenital abnormalities, hypotonia and seizures. NBIA: neurodegeneration associated with brain iron accumulation (type 1 refers to NBIA produced by PKAN deficiency whereas type 2 is due to PLA2G6 deficiency or PLAN: PLA2G6 associated neurodegeneration); NTE: neuropathy target enterase deficiency; PANK2: pantothenate kinase 2 deficiency; PLA2G6: phospholipase A2 deficiency. PVWMH: periventricular White matter hyperintensities; SLS: Sjöegren Larsson syndrome; SN: substantia nigra. 


\begin{tabular}{|c|c|c|c|c|c|}
\hline $\begin{array}{c}\text { PERIPHERAL } \\
\text { NEUROPATHY and } \\
\text { SPINAL CORD } \\
\text { involvement }\end{array}$ & $\begin{array}{l}\text { AGE AT } \\
\text { ONSET }\end{array}$ & MAJOR SYMPTOMS & $\begin{array}{l}\text { DEFECTIVE } \\
\text { ENZYME }\end{array}$ & $\begin{array}{l}\text { DEFECTIVE } \\
\text { GENE } \\
\text { (Inheritance) }\end{array}$ & $\begin{array}{c}\text { BIBLIOGRAPHIC } \\
\text { REFERENCES }\end{array}$ \\
\hline & $\begin{array}{l}\text { Adolescence } \\
\text { to adulthood } \\
\text { Early } \\
\text { childhood }\end{array}$ & $\begin{array}{l}\text { HSAN type } 1 \text { is the most common form. } \\
\text { Most cases: autosomal dominant, late onset (typically } \\
\text { between the } 2 \text { nd and } 4 \text { th decade), slow progression, distal } \\
\text { sensory involvement (plantar ulcers predominantly affecting } \\
\text { the lower limbs and lancinating pain attacks). Muscle } \\
\text { weakness and cataract. Motor neuron degeneration can } \\
\text { occur. Considerable clinical heterogeneity in the time of } \\
\text { onset and the severity of the symptoms. SPTLC1 and SPTCL2 } \\
\text { are the most common mutations. } \\
\text { Severe early hypotonia and muscle weakness with sensory } \\
\text { and autonomic neuropathy associated with global } \\
\text { hypotrophy, developmental retardation, vocal cord paresis, } \\
\text { anhydrosis, cataract, and severe respiratory problems. } \\
\text { Mutation p.S331 at SPTLC1 is associated with a very } \\
\text { severe phenotype. }\end{array}$ & $\begin{array}{l}\text { Serine } \\
\text { palmitoyltransferase } \\
\text { (SPT) is the most } \\
\text { common } \\
\text { (corresponding to } \\
\text { SPTLC1 and SPTCL2 } \\
\text { genes) }\end{array}$ & $\begin{array}{l}\text { AD. Genes: } \\
\text { SPTLC1, SPTLC2, } \\
\text { ATL1, RAB7A } \\
\text { and DNMT1 } \\
\\
\text { SPTLC1 and } \\
\text { SPTLC2, unknown } \\
\text { inheritance, de } \\
\text { novo, isolated } \\
\text { cases }\end{array}$ & $\begin{array}{l}\text { Dick } 1993 \\
\text { Rotthier, et al. } \\
2012\end{array}$ \\
\hline
\end{tabular}




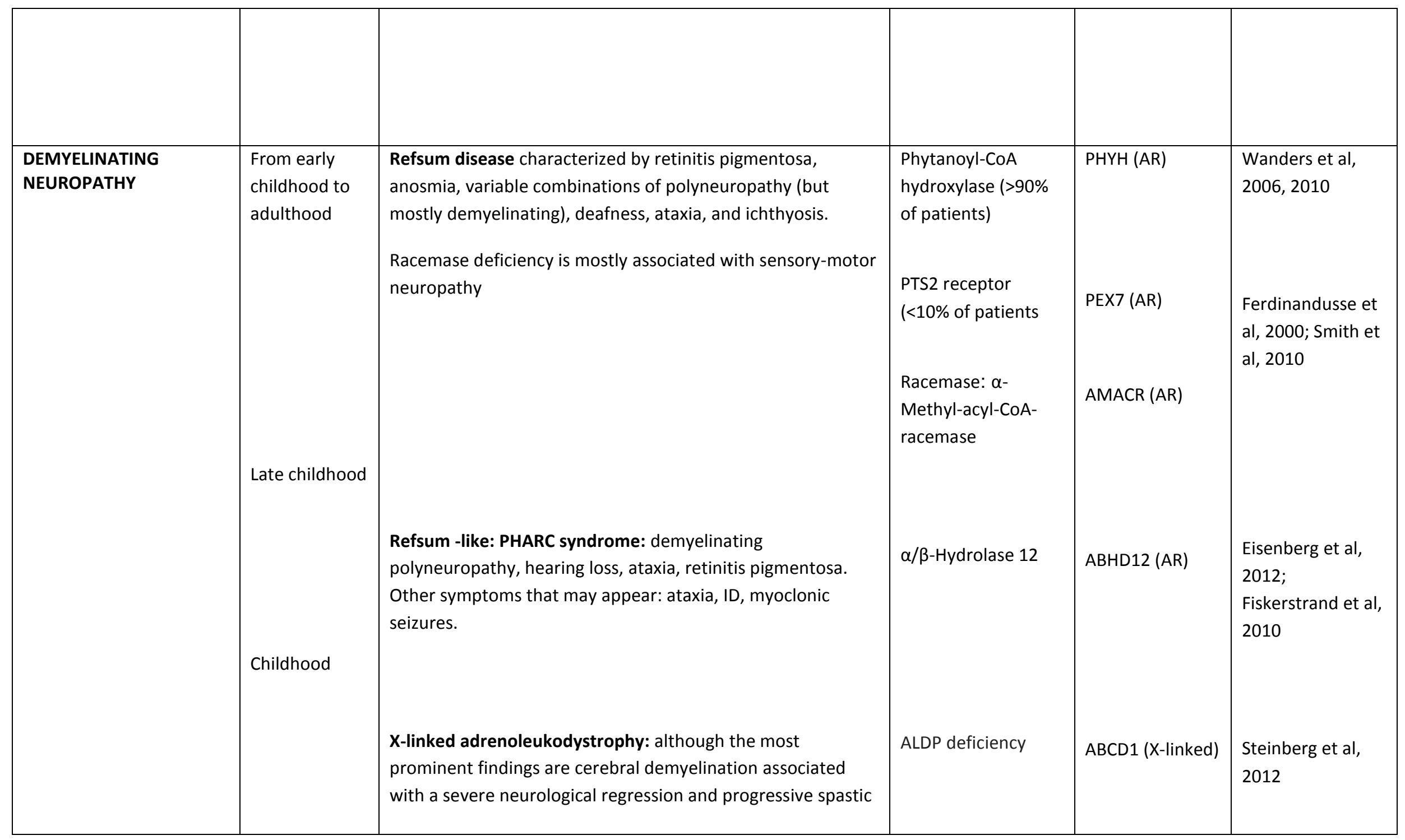




\begin{tabular}{|c|c|c|c|c|c|}
\hline & $\begin{array}{l}\text { Adolescence } \\
\text { to adulthood }\end{array}$ & $\begin{array}{l}\text { quadriparesis with cognitive decline, demyelinating (and } \\
\text { motor) polyneuropathy may also be present. } \\
\text { Adrenomyeloneuropathy: although the spinal cord } \\
\text { involvement and SP are the most prominent signs, axonal } \\
\text { and/or demyelinating neuropathy are frequent. }\end{array}$ & ALDP deficiency & ABCD1 (X-linked) & $\begin{array}{l}\text { Steinberg et al, } \\
2012\end{array}$ \\
\hline AXONAL NEUROPATHY & $\begin{array}{l}\text { Infantile to } \\
\text { childhood }\end{array}$ & $\begin{array}{l}\text { Associated with Spastic Paraparesis (SP) } \\
\text {-SP and cognitive regression. Symptoms such as hearing } \\
\text { impairment, facial dysmorphism, hepatic involvement and } \\
\text { renal cysts may be present. } \\
\text {-Severe sensory motor polyneuropathy with spastic } \\
\text { paraparesis, abnormal gait, pes equinovarus and borderline } \\
\text { intelligence. Brain MRI: CC and cerebellar hypoplasia ( } 1 \\
\text { single case described) } \\
\text { - Other causes of sensory motor neuropathy and SP : PLA2G6, } \\
\text { CYP2U1 (SPG56), GBA2 (SPG46) and B4GALNT1 (SPG26) (see } \\
\text { table that refers to central nervous system involvement) }\end{array}$ & $\begin{array}{l}\text { Different proteins } \\
\text { related to PBD } \\
\text { Arylsulfatase family } \\
\text { member } 1\end{array}$ & $\begin{array}{l}\text { PEX genes (AR) } \\
\text { ARSI (AR) }\end{array}$ & $\begin{array}{l}\text { Waterham et al, } \\
2012\end{array}$ \\
\hline
\end{tabular}




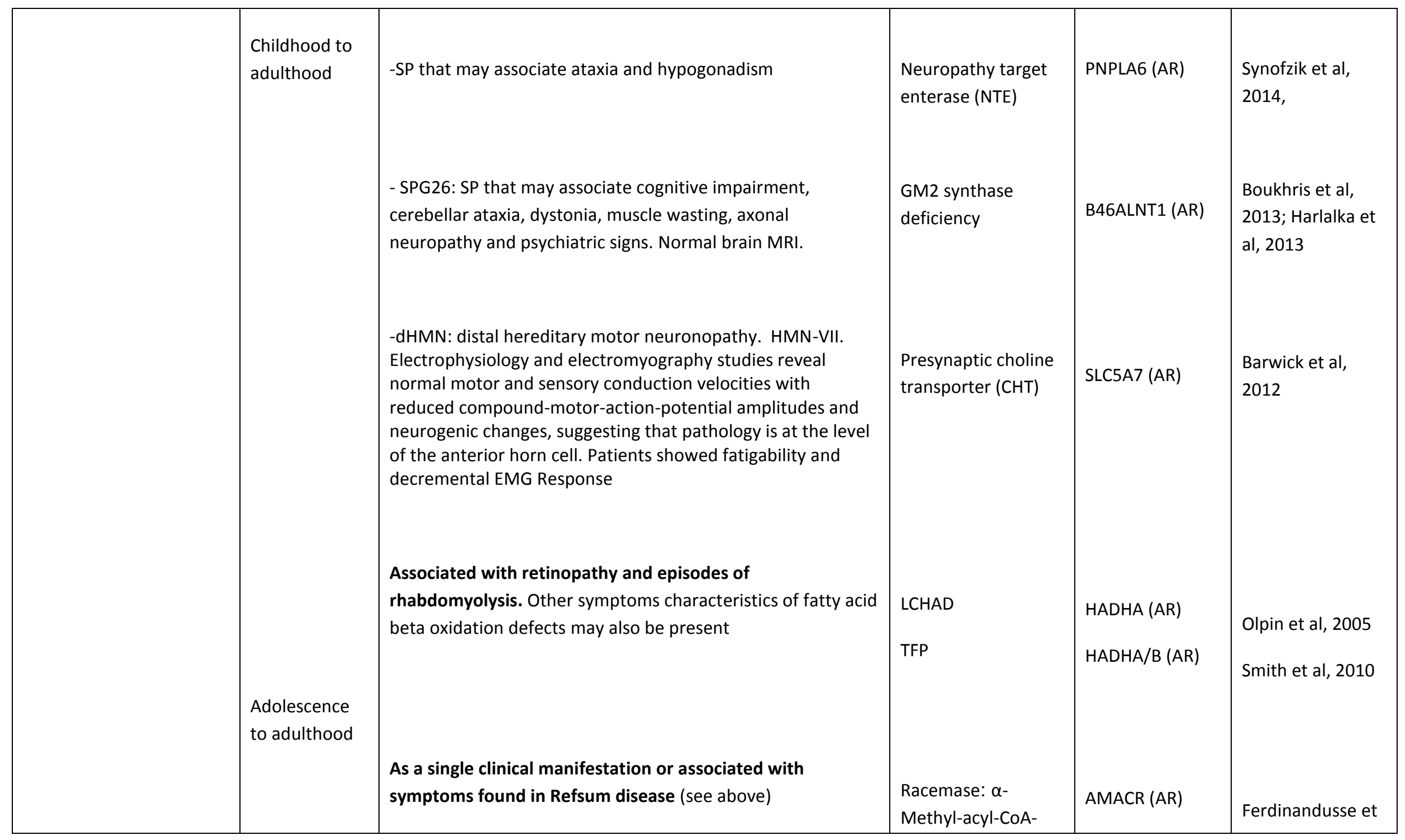




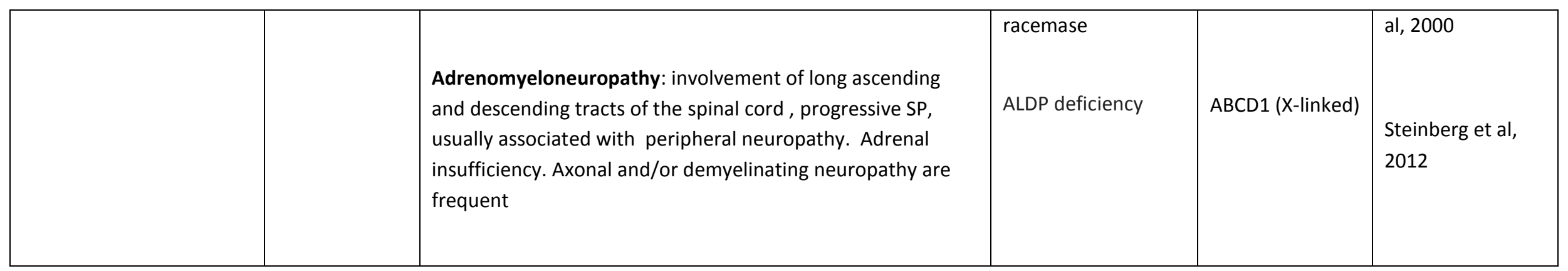

\section{Abbreviations:}

AR: autosomal recessive. AD: autosomal dominant. CHT: choline transporter. dHMNs: distal hereditary motor neuronopathies. HSAN: inherited sensory and autonomic neuropathy. HSAN1, OMIM\#605712 and \#605713. ID: Intellectual disability. LCHAD: long-chain 3-hydroxyacyl-CoA dehydrogenase deficiency. NTE: neuropathy target enterase deficiency. PBD: peroxisomal biogenesis disorders. SP: spastic paraparesis. SPT: Serine palmitoyltransferase. TFP: trifunctional protein deficiency 


\begin{tabular}{|c|c|c|c|c|c|}
\hline $\begin{array}{c}\text { SKELETAL AND } \\
\text { CARDIAC MUSCLE } \\
\text { involvement }\end{array}$ & $\begin{array}{l}\text { AGE AT } \\
\text { ONSET }\end{array}$ & MAJOR ASSOCIATED SYMPTOMS & $\begin{array}{l}\text { DEFECTIVE } \\
\text { ENZYME }\end{array}$ & $\begin{array}{l}\text { DEFECTIVE } \\
\text { GENE } \\
\text { (Inheritance) }\end{array}$ & $\begin{array}{l}\text { BIBLIOGRAPHIC } \\
\text { REFERENCES }\end{array}$ \\
\hline & $\begin{array}{l}\text { Childhood to } \\
\text { adulthood }\end{array}$ & $\begin{array}{l}\text { Episodes of rhabdomyolisis and myalgia may appear. } \\
\text { Retinopathy and sensory motor neuropathy are also } \\
\text { characteristic. Other symptoms characteristics of fatty acid } \\
\text { beta oxidation defects may also be present. }\end{array}$ & $\begin{array}{l}\text { LCHAD } \\
\text { TFP }\end{array}$ & $\begin{array}{l}\text { HADHA (AR) } \\
\text { HADHA/B (AR }\end{array}$ & Olpin et al, 2005 \\
\hline $\begin{array}{l}\text { MYOPATHY (muscular } \\
\text { dystrophy, weakness, } \\
\text { elevated CK) }\end{array}$ & Infantile & $\begin{array}{l}\text { Severe myopathic phenotype at birth that gradually } \\
\text { Improves. Early infantile: severe hypotonia, absent deep } \\
\text { tendon reflexes, weak cry, recurrent apnea of newborn. } \\
\text { Later on: facial weakness, decreased muscle tone, delayed } \\
\text { motor milestones, positive Gower sign. One patient evolved } \\
\text { towards normal gait and residual pes cavus at adult age. }\end{array}$ & $\begin{array}{l}\text { 3-hydroxyacyl- } \\
\text { CoA dehydratase } 1 \\
\text { (HACD1) }\end{array}$ & PTPLA (AR) & $\begin{array}{l}\text { Muhammad et al, } \\
2013\end{array}$ \\
\hline
\end{tabular}




\begin{tabular}{|c|c|c|c|c|c|}
\hline & $\begin{array}{l}\text { Infantile to } \\
\text { childhood }\end{array}$ & $\begin{array}{l}\text { Chanarin-Dorfman syndrome: Myopathy (elevated CK), liver } \\
\text { steatosis with hepatomegaly, ataxia, neurosensory hearing } \\
\text { loss, cataracts, nystagmus, strabismus and ID with icthyosis.. } \\
\text { Intracellular accumulation of triacylglycerol droplets in } \\
\text { tissues }\end{array}$ & $\begin{array}{l}\text { Alpha/beta } \\
\text { hydrolase } 5 \\
(\mathrm{ABHD} 5)\end{array}$ & ABHD5 (AR) & $\begin{array}{l}\text { Lefèvre et al, } \\
2001\end{array}$ \\
\hline \multirow[t]{3}{*}{$\begin{array}{l}\text { MYOPATHY (muscular } \\
\text { dystrophy, weakness, } \\
\text { elevated CK) } \\
\text { +/- CARDIOMYOPATHY }\end{array}$} & $\begin{array}{l}\text { Infantile } \\
\text { Infantile }\end{array}$ & $\begin{array}{l}\text { Early.onset muscle wasting, mental retardation and abnormal } \\
\text { mitochondrial morphology (enlarged mitochondria). Some } \\
\text { patients may have dilated cardiomyopathy and seizures } \\
\text { Severe hypotonia with elevated CK, seizures and other } \\
\text { associated signs +/- cardiomyopathy }\end{array}$ & $\begin{array}{l}\text { Choline kinase beta } \\
\text { (CHKB) deficiency } \\
\text { IEM of the dolichols. } \\
\text { All lead to } \\
\text { hypoglycosylated } \\
\text { target proteins and } \\
\text { belong to the CDG } \\
\text { syndromes. }\end{array}$ & CHKB (AR) & $\begin{array}{l}\text { Mitsuhashi et al, } \\
2011\end{array}$ \\
\hline & & $\begin{array}{l}\text {-Severe hypotonia with elevated CK, intractable seizures, } \\
\text { ichthyosis with loss of hair, severe liver dysfunction and } \\
\text { progressive dilated cardiomyopathy. Mild coagulopathy } \\
\text { icthyosis and mild ID may be also present. }\end{array}$ & DK1 & DK1 (AR) & $\begin{array}{l}\text { Lefeber et al., } \\
2011\end{array}$ \\
\hline & & $\begin{array}{l}\text {-Acquired microcephaly, severe hypotonia with elevated CK, } \\
\text { and early-onset myoclonic epilepsy and cerebellar hypoplasia } \\
\text { elevated transaminases and low ATIII mild ID, muscular } \\
\text { dystrophy. Stroke-like episodes and dilated cardiomiopathy }\end{array}$ & DPM 1-3 & DPM1-3 (AR) & $\begin{array}{l}\text { Barone et al., } \\
2012\end{array}$ \\
\hline
\end{tabular}




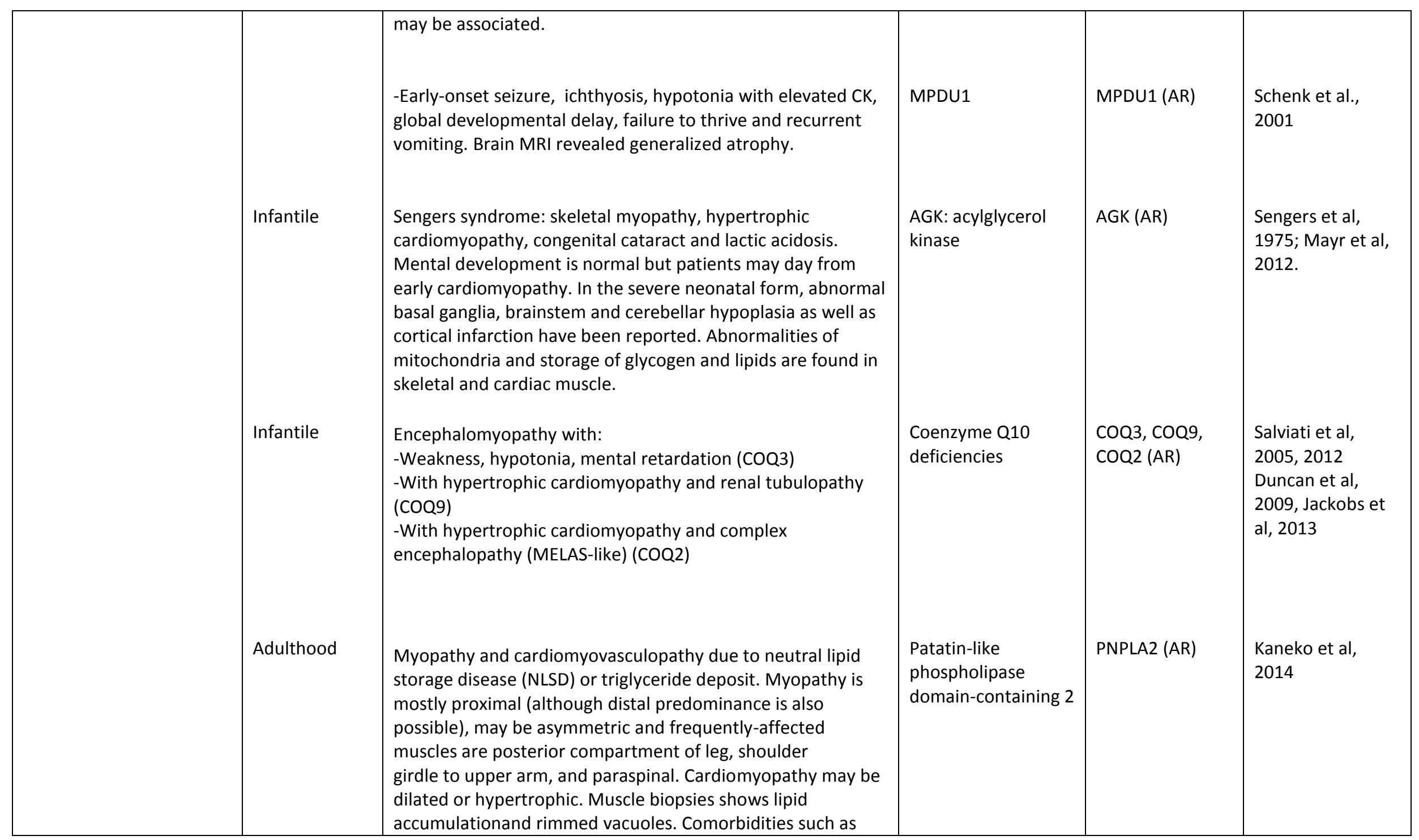




\begin{tabular}{|c|c|c|c|c|c|}
\hline & & $\begin{array}{l}\text { hyperlipidemia, diabetes mellitus, and pancreatitis have been } \\
\text { described. }\end{array}$ & & & \\
\hline $\begin{array}{l}\text { PRIMARY CARDIAC } \\
\text { PRESENTATIONS }\end{array}$ & $\begin{array}{l}\text { Infantile } \\
\text { Any age, } \\
\text { antenatal to } \\
\text { adulthood } \\
\text { Infantile }\end{array}$ & $\begin{array}{l}\text { Dilated cardiomyopathy } \\
\text { Primary cardiac presentation without } \\
\text { seizures, dysmorphic features, ichthyosis or intellectual } \\
\text { disability. Dilated cardiomyopathy that leads to life- } \\
\text { threatening dysrhythmias, persistent transaminase elevations } \\
\text { with decreased Factors XI and ATIII, and microcytic anemia, } \\
\text { and the ensuing neutropenia. } \\
\text { Barth syndrome: the classical presentation includes } \\
\text { cardiomyopathy, skeletal muscle weakness, neutropenia and } \\
\text { growth retardation. Cardiomyopathy is the most severe } \\
\text { presentation (biventricular dilatation or left-ventricular non- } \\
\text { compactation are the initial signs). Excretion of 3- } \\
\text { methylglutaconic acid is characteristic but not constant. } \\
\text { Hypertrophic cardiomyopathy } \\
\text { Sengers syndrome: described above. Important to highlight } \\
\text { that the clinical course is dominated by the cardiac problems } \\
\text { and is variable, ranging from a late onset chronic progressive } \\
\text { form with survival into the fourth decade, over patients } \\
\text { receiving heart transplantation in childhood to a fatal } \\
\text { neonatal onset form. }\end{array}$ & $\begin{array}{l}\text { IEM of the dolichols. } \\
\text { All lead to } \\
\text { hypoglycosylated } \\
\text { target proteins and } \\
\text { belong to the CDG } \\
\text { syndromes. } \\
\text { Cardiolipin (CL) } \\
\text { AGK: acylglycerol } \\
\text { kinase }\end{array}$ & $\begin{array}{l}\text { DK1 (AR) } \\
\text { TAZ (X-linked) }\end{array}$ & $\begin{array}{l}\text { Bione et al, } 1996 \\
\text { Barth et al, 2004; } \\
\text { Clarke et al. } 2013\end{array}$ \\
\hline
\end{tabular}




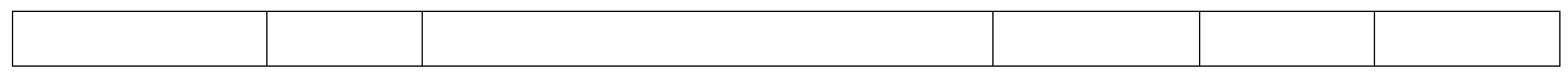

\section{TABLE 3 Muscular and cardiac symptoms}

\section{Abbreviations:}

ABDH5: Alpha/beta hydrolase 5. AR: autosomal recessive. AD: autosomal dominant. CL: Cardiolipin. ID: Intellectual disability. HSAN: inherited sensory and autonomic neuropathy. CK: Creatine Kinase. HACD1: 3-hydroxyacyl-CoA dehydratase 1. DPM; dolichyl-phosphate-D-mannose: protein O-D-mannosyltransferase. ID: Intellectual disability. MPDU1: Mannose-P-Dolichol Utilization Defect 1. NLSDM: neutral lipid storage disease miopathy. NTE: neuropathy target enterase deficiency. PNPLA2: Patatin-like phospholipase domain-containing 2. SP: spastic paraparesis. SPT: Serine palmitoyltransferase. 


\begin{tabular}{|c|c|c|c|c|c|}
\hline $\begin{array}{l}\text { Syndrome/ } \\
\text { enzyme defect } \\
\text { (gene defect) }\end{array}$ & Cataract & $\begin{array}{c}\text { Retinal } \\
\text { dystrophies }\end{array}$ & $\begin{array}{c}\text { Optic nerve } \\
\text { degeneratio } \\
n\end{array}$ & Major symptoms & \\
\hline $\begin{array}{l}\text { Sengers syndrome (AR) } \\
(A G K)\end{array}$ & $\begin{array}{c}+ \\
\text { may be } \\
\text { isolated }\end{array}$ & & & $\begin{array}{l}\text { Hypertrophic cardiomyopathy, myopathy, lactic acidosis, } \\
\text { 3-methylglutaconic acid excretion. Cataract may be isolated. }\end{array}$ & $\begin{array}{l}\text { Sengers et al, } \\
1975\end{array}$ \\
\hline $\begin{array}{l}\text { Lowe Syndrome (X-linked) } \\
\text { (OCRL, encoding } \\
\text { phosphatidylinositol } \\
4,5 \text { bisphosphate 5- } \\
\text { phosphatase) }\end{array}$ & + & & & $\begin{array}{l}\text { Renal Fanconi syndrome, mental retardation. } \\
\text { ( } \\
\text { PS: OCRL1 mutations are also found in some forms of Dent } \\
\text { disease without any cataract (Hoopes 2005) }\end{array}$ & $\begin{array}{l}\text { Attree, et al } \\
\text { 1992, } \\
\text { Suchy et al, } \\
2002 \text {. }\end{array}$ \\
\hline $\begin{array}{l}\text { Chanarin-Dorfman (AR) } \\
\text { (ABHD5.CGI58) }\end{array}$ & + & & & $\begin{array}{l}\text { Congenital ichthyosis, hepatomegaly with liver steatosis, mental } \\
\text { retardation, myopathy, decreased hearing }\end{array}$ & $\begin{array}{l}\text { Lefèvre et al, } \\
2001\end{array}$ \\
\hline $\begin{array}{l}\text { Glucocerebrosidase } 2 \text { (AR) } \\
\text { (GBA2) }\end{array}$ & + & & & $\begin{array}{l}\text { Early onset spastic ataxia, developmental delay, axonal sensory } \\
\text { neuropathy, hearing loss. Brain MRI corpus callosum and } \\
\text { cerebellar atrophy } \\
\text { (Hammer et al 2013) }\end{array}$ & $\begin{array}{l}\text { Hammer et al, } \\
2013\end{array}$ \\
\hline $\begin{array}{l}\mathrm{N} \text {-acetylgalactosaminyl } \\
\text { transferase } 1 \text { (AR) } \\
\text { (B4GALNT1) }\end{array}$ & $\begin{array}{c}+ \\
\text { (rare) }\end{array}$ & & & $\begin{array}{l}\text { Early onset spastic paraplegia, developmental delay, cerebellar } \\
\text { symptoms, dystonia, muscle wasting, axonal neuropathy. }\end{array}$ & $\begin{array}{l}\text { Harlalka et al, } \\
2013\end{array}$ \\
\hline $\begin{array}{l}\text { 3-phosphoglycerate } \\
\text { dehydrogenase deficiency } \\
\text { (AR) } \\
\text { (PHGDH) }\end{array}$ & + & & & $\begin{array}{l}\text { Congenital cataract with microcephaly, profound mental } \\
\text { retardation, severe spastic paraplegia, nystagmus and } \\
\text { intractable seizures. One late onset form described with } \\
\text { congenital cataract followed by atypical neuropathy. }\end{array}$ & $\begin{array}{l}\text { Meneret et al, } \\
2012\end{array}$ \\
\hline
\end{tabular}




\begin{tabular}{|c|c|c|c|c|}
\hline $\begin{array}{l}\text { Smith Lemli Opitz syndrome } \\
\text { (AR) } \\
(D H C R 7)\end{array}$ & $\begin{array}{c}+ \\
\text { (incidental) }\end{array}$ & & $\begin{array}{l}\text { Large and variable spectrum of congenital anomalies including } \\
\text { distinctive facial features, microcephaly, intellectual disability, } \\
\text { behavioral problems, malformations of the heart, lungs, kidneys, } \\
\text { gastrointestinal tract, and genitalia. }\end{array}$ & $\begin{array}{l}\text { Waterham et } \\
\text { al, } 2006\end{array}$ \\
\hline $\begin{array}{l}\text { Conradi Hunermann } \\
\text { syndrome (dominant X- } \\
\text { linked) } \\
(E B P)\end{array}$ & + & & $\begin{array}{l}\text { X-linked dominant chondrodysplasia type II (asymmetric } \\
\text { rhizomelic shortening, epiphyseal calcific stippling) with } \\
\text { ichthyosiform erythrodermia }\end{array}$ & $\begin{array}{l}\text { Waterham et } \\
\text { al, } 2006\end{array}$ \\
\hline $\begin{array}{l}\text { Mevalonate kinase deficiency } \\
\text { (classic form)(AR) } \\
(M V K)\end{array}$ & $\begin{array}{c}+ \\
\text { (incidental) }\end{array}$ & $\begin{array}{c}\text { RP } \\
\text { may be } \\
\text { isolated } \\
\text { (incidental) }\end{array}$ & $\begin{array}{l}\text { Multisystemic disease with recurrent inflammatory crisis, } \\
\text { hepatosplenomegaly, lymphadenopathy and recurrent severe } \\
\text { anemia } \\
\text { Clinical evaluation of } 3 \text { Dutsch patients diagnosed as classic } \\
\text { form of RP showed variable extra-ocular symptoms (recurrent } \\
\text { childhood febrile crises, mild ataxia, and renal failure). All } 3 \\
\text { affected individuals showed a low MK activity and high levels of } \\
\text { urinary mevalonic acid (Siemiatkowska 2013) }\end{array}$ & $\begin{array}{l}\text { Siemiatkowska } \\
\text { et al, } 2013\end{array}$ \\
\hline $\begin{array}{l}\text { Cerebrotendinous } \\
\text { xanthomatosis (AR) } \\
\text { (CYP27A1) }\end{array}$ & + & & $\begin{array}{l}\text { Neonatal jaundice, diarrhea, mental retardation, late infantile } \\
\text { cataract, Late onset tendon xanthomata }\left(2^{\text {nd }} \text { decade), }\right. \\
\text { progressive neurological dysfunction (spastic paraplegia, ataxia), } \\
\text { psychiatric symptoms }\end{array}$ & $\begin{array}{l}\text { Berginer et al, } \\
1984\end{array}$ \\
\hline $\begin{array}{l}\text { Fatty acid elongase (AR) (AD) } \\
\text { (ELOVL4) }\end{array}$ & $\begin{array}{c}+ \\
\text { recessive }\end{array}$ & $\begin{array}{l}\text { Stargardt } \\
\text { type lii } \\
\text { dominant }\end{array}$ & $\begin{array}{l}\text { Congenital ichthyosis and neurological symptoms resembling } \\
\text { Sjögren-Larsson disease (Aldamesh 2011) } \\
\text { Heterozygous ELOVL4 mutations display an autosomal dominant } \\
\text { juvenile form of isolated macular degeneration (Zhang et al } \\
\text { 2001) }\end{array}$ & $\begin{array}{l}\text { Zhang et al, } \\
2001\end{array}$ \\
\hline $\begin{array}{l}\text { Sjogren Larsson (AR) } \\
(A L D H 3 A 2)\end{array}$ & $\begin{array}{c}+ \\
\text { may be } \\
\text { isolated }\end{array}$ & RP & $\begin{array}{l}\text { Hypertrophic cardiomyopathy, myopathy, lactic acidosis, 3- } \\
\text { methylglutaconic acid excretion (Willemsen 2001) }\end{array}$ & $\begin{array}{l}\text { Willemsen et } \\
\text { al, } 2001\end{array}$ \\
\hline $\begin{array}{l}\text { Refsum disease (AR) } \\
(P H Y H)\end{array}$ & + & $\begin{array}{c}\text { RP } \\
\text { cardinal sign }\end{array}$ & $\begin{array}{l}\text { Retinitis pigmentosa, cerebellar ataxia, chronic polyneuropathy, } \\
\text { sensorineural hearing loss, anosmia, skeletal malformations, } \\
\text { ichthyosis }\end{array}$ & $\begin{array}{l}\text { Wanders et al, } \\
2011\end{array}$ \\
\hline
\end{tabular}




\begin{tabular}{|c|c|c|c|c|c|}
\hline $\begin{array}{l}\text { PHARC syndrome (AR) } \\
(A B H D 12)\end{array}$ & + & $\begin{array}{l}\text { RP } \\
\text { may be } \\
\text { isolated }\end{array}$ & & $\begin{array}{l}\text { Cataract, hearing loss and predominantly demyelinating } \\
\text { peripheral neuropathy. RP develops in the second or third } \\
\text { decade. RP may be isolated. } \\
\text { (Wotrmann this issue) }\end{array}$ & $\begin{array}{l}\text { Nishiguchi et al, } \\
2014\end{array}$ \\
\hline $\begin{array}{l}\text { PZO Biogenesis defects } \\
\text { (AR) } \\
\text { (several PEX) }\end{array}$ & + & RP & OA & $\begin{array}{l}\text { Various phenotypes ranging from typical Zellweger syndrome to } \\
\text { neonatal ALD, infantile Refsum disease and late onset } \\
\text { polyneuropathy resembling Charcot Marie Tooth disease }\end{array}$ & $\begin{array}{l}\text { Wanders et al, } \\
2011\end{array}$ \\
\hline $\begin{array}{l}\text { Phospholipase } \mathbf{A} 2 \text { group } \mathbf{V} \\
\text { (AR) } \\
\text { (PNPLA5) }\end{array}$ & & $\begin{array}{l}\text { Benign fleck } \\
\text { retina }\end{array}$ & & $\begin{array}{l}\text { Benign yellow-white retinal lesions or flecks with otherwise } \\
\text { normal retinal findings (Sergouniotis 2011) }\end{array}$ & $\begin{array}{l}\text { Sergouniotis et } \\
\text { al, } 2011\end{array}$ \\
\hline $\begin{array}{l}\text { Retinal pigment epithelium- } \\
65 \mathrm{kD} \text { protein isomerase } \\
\text { (RPE65) }\end{array}$ & & $\begin{array}{l}\text { AR RP } \\
\text { AD RP } \\
\text { LCA }\end{array}$ & & $\begin{array}{l}\text { LCA, recessive RP, and dominant RP with choroidal involvement } \\
\text { (Hanein S et al 2004) }\end{array}$ & $\begin{array}{l}\text { Hanein et al, } \\
2004\end{array}$ \\
\hline $\begin{array}{l}\text { ABCA4 transporter of the } \\
\text { retinal phospholipid } \\
\text { compound, N-retinylidene- } \\
\text { phosphatidylethanolamine }\end{array}$ & & $\begin{array}{l}\text { AR Stargardt } \\
\text { AR CRD } \\
\text { AR RP } 19\end{array}$ & & $\begin{array}{l}\text { CRD individuals experience severe loss in visual acuity and color } \\
\text { vision and display significant atrophy of the central retina or } \\
\text { macula. This is followed by progressive loss in peripheral vision } \\
\text { and night blindness. } \\
\text { Unlike typical RP, affected individuals with RP } 19 \text { show an early } \\
\text { loss in central vision and atrophy of the macula in addition to } \\
\text { the characteristic features of RP (Zhang et al 2013) }\end{array}$ & $\begin{array}{l}\text { Sparrow et al, } \\
2010 \\
\text { Zhang et al, } \\
1999\end{array}$ \\
\hline $\begin{array}{l}\text { PITPNM3, } \\
\text { phosphatidylinositol transfer } \\
\text { membrane-associated family } \\
\text { member } 3\end{array}$ & & $\begin{array}{l}\text { AD cone } \\
\text { dystrophy }\end{array}$ & & $\begin{array}{l}\text { Patients display subnormal visual acuity and light sensitivity } \\
\text { from childhood. Early signs of macular degeneration then appear } \\
\text { with a progressive decrease in visual acuity leading to blindness } \\
\text { in early adulthood. ERG testing shows a progressive loss of } \\
\text { photoreceptor function restricted to the cones. (Köhn,et al 2007) }\end{array}$ & $\begin{array}{l}\text { Köhn et al, } \\
2007\end{array}$ \\
\hline $\begin{array}{l}\text { RBP3, interphotoreceptor } \\
\text { binding protein } \\
(I R B P)\end{array}$ & & AR RP66 & & $\begin{array}{l}\text { IRBP protein binds and transports retinoids in the } \\
\text { interphotoreceptor matrix between the retinal pigmentary } \\
\text { epithelium and photoreceptors (den Hollander 2009) }\end{array}$ & $\begin{array}{l}\text { den Hollander } \\
\text { et al, } 2009\end{array}$ \\
\hline
\end{tabular}




\begin{tabular}{|c|c|c|c|}
\hline $\begin{array}{l}\text { CYP4V2 (CYP4V2) } \\
\text { may have important roles in } \\
\text { eicosanoid metabolism. } \\
\text { Catalysts of } \omega-3 \text { and } \omega-6 \\
\text { oxidations of polyunsaturated } \\
\text { fatty acids }\end{array}$ & $\begin{array}{l}\text { Bietti's } \\
\text { crystalline } \\
\text { dystrophy } \\
\quad \text { AR }\end{array}$ & $\begin{array}{l}\text { BCD is characterized by the presence of yellow-white crystals } \\
\text { and/or complex lipid deposits in the cornea and retina, atrophy } \\
\text { and degeneration of the retinal pigmented epithelium and } \\
\text { sclerosis of the choroidal capillaries. These symptoms progress } \\
\text { from visual field constriction to eventual night blindness. BCD is } \\
\text { a progressive disease, but patients as young as } 16 \text { to } 17 \text { years of } \\
\text { age have been diagnosed (Nakano et al 2012), }\end{array}$ & $\begin{array}{l}\text { Nakano et al, } \\
2012\end{array}$ \\
\hline $\begin{array}{l}\text { RBP } 4 \text { (serum retinol binding } \\
\text { protein) (AR) }\end{array}$ & $\mathbf{R P}$ & $\begin{array}{l}\text { Affected siblings had no detectable serum RBP, one sixth of } \\
\text { normal retinol levels, and normal retinyl esters. The retinal } \\
\text { pigment epithelium was severely affected, but there were no } \\
\text { changes to other organs. This gives evidence for an alternative } \\
\text { tissue source of vitamin A, presumably retinyl esters from } \\
\text { chylomicron remnants_(Seeliger MW et al 1999) }\end{array}$ & $\begin{array}{l}\text { den Hollander } \\
\text { et al, } 2009 \\
\text { Seeliger et al, } \\
1999\end{array}$ \\
\hline $\begin{array}{l}\text { Lecithin retinol } \\
\text { acyltransferase (AR) } \\
(L R A T)\end{array}$ & $\begin{array}{l}\text { RP } \\
\text { LCA }\end{array}$ & $\begin{array}{l}\text { Recessive RP, severe early-onset; recessive LCA (Thompson } \\
\text { 2001) }\end{array}$ & $\begin{array}{l}\text { Thompson et } \\
\text { al, } 2001\end{array}$ \\
\hline $\begin{array}{l}\text { RDH11 (AR) } \\
\text { RDH11 protein is a widely- } \\
\text { expressed enzyme with a role } \\
\text { in oxidizing 11-cis-retinol to } \\
\text { 11-cis-retinal similar to RDH } \\
1,5 \text { and } 12\end{array}$ & $\begin{array}{c}\mathrm{RP} \\
\text { syndromic }\end{array}$ & $\begin{array}{l}\text { RP with facial dysmorphology, developmental delay, and short } \\
\text { stature; RP-associated ophthalmological findings included salt- } \\
\text { and-pepper retinopathy, attenuation of the arterioles and } \\
\text { generalized rod-cone dysfunction with almost extinguished } \\
\text { electroretinogram ( Xie et al 2014) }\end{array}$ & $\begin{array}{l}\text { Fingert et al, } \\
2008 \\
\text { Xie et al, } 2014\end{array}$ \\
\hline $\begin{array}{l}\text { RDH12 (AR and AD) } \\
11-\text { cis retinol dehydrogenase } \\
12\end{array}$ & $\begin{array}{l}\text { AR LCA } \\
\text { with severe } \\
\text { childhood } \\
\text { retinal } \\
\text { dystrophy; } \\
\text { AD RP }\end{array}$ & $\begin{array}{l}\text { Symptoms include severe progressive rod-cone dystrophy and } \\
\text { macular atrophy; may account for } 4 \% \text { of recessive LCA (Fingert } \\
\text { et al 2008, Perrault et al 2004) }\end{array}$ & $\begin{array}{l}\text { Perrault et al, } \\
2004 \\
\text { Yamamoto et } \\
\text { al, } 1999\end{array}$ \\
\hline
\end{tabular}




\begin{tabular}{|c|c|c|c|}
\hline $\begin{array}{l}\text { RDH5 (AR) } \\
\text { 11-cis retinol dehydrogenase } \\
5 \\
\text { (same pathway as in RDH11 } \\
\text { and 12) }\end{array}$ & $\begin{array}{l}\text { Cone } \\
\text { dystrophy, } \\
\text { late onset }\end{array}$ & $\begin{array}{l}\text { Stationary night blindness with subretinal spots and delayed } \\
\text { dark adaptation; extremely delayed rod and cone resensitization } \\
\text { in null mutation (AV Cideciyan et al 1999, H Yamamoto et al } \\
\text { 1999) }\end{array}$ & $\begin{array}{l}\text { Cideciyan et, } \\
1999\end{array}$ \\
\hline $\begin{array}{l}\text { Ceramide kinase like(AR) } \\
(C E R K L)\end{array}$ & $\begin{array}{c}\text { RP } \\
\text { non } \\
\text { syndromic }\end{array}$ & $\begin{array}{l}\text { Primary dysfunction or loss of cone photoreceptors and then of } \\
\text { rod photoreceptors. Patients present with a progressive loss of } \\
\text { central vision, visual field constriction and nyctalopia. (Aleman } \\
\text { TS 2009) }\end{array}$ & $\begin{array}{l}\text { Aleman et al, } \\
2009\end{array}$ \\
\hline $\begin{array}{l}\text { Dehydrodolichyl diphosphate } \\
\text { synthase (AR) } \\
\text { (DHDDS) }\end{array}$ & $\begin{array}{c}\text { RP } \\
\text { non } \\
\text { syndromic }\end{array}$ & $\begin{array}{l}\text { DHDDS K42E and T206A missense mutations have been linked } \\
\text { to non syndromal RP( Züchner S et al 2011, Zelinger L et al 2011) }\end{array}$ & $\begin{array}{l}\text { Zelinger et al, } \\
2011 \\
\text { Züchner et al, } \\
2011\end{array}$ \\
\hline $\begin{array}{l}\text { Joubert syndrome (AR) } \\
\text { (INPP5E, encoding inositol } \\
\text { polyphosphate-5-phosphatase } \\
\text { E) }\end{array}$ & $\mathbf{R P}$ & $\begin{array}{l}\text { Absence or underdevelopment of the cerebellar vermis and a } \\
\text { malformed brain stem (molar tooth sign). Most common } \\
\text { features include ataxia, hyperpnea, sleep apnea, abnormal eye } \\
\text { and tongue movements, and hypotonia., with variably } \\
\text { associated retinitis pigmentos, nephronophthisis,liver fibrosis } \\
\text { and polydactyly .It is included in the newly emerging group of } \\
\text { 'ciliopathies' (Bielas 2009) }\end{array}$ & $\begin{array}{l}\text { Bielas et al, } \\
2009\end{array}$ \\
\hline $\begin{array}{l}\text { Phosphocholine citidylyl } \\
\text { transferase (AR) } \\
(P C Y T 1 A)\end{array}$ & CRD & $\begin{array}{l}\text { Spondylometaphyseal dysplasia, short stature with rhizomelia, } \\
\text { platyspondyly, early-onset visual impairment with pigmentary } \\
\text { maculopathy and cone-rod dysfunction (Wortmann this issue) }\end{array}$ & $\begin{array}{l}\text { Yamamoto et } \\
\text { al, } 2014\end{array}$ \\
\hline $\begin{array}{l}\text { Boucher-Neuhauser } \\
\text { syndrome (AR) } \\
\text { (PNPLA6) }\end{array}$ & $\mathbf{R P}$ & $\begin{array}{l}\text { Ataxia with cerebellar atrophy, chorioretinal degeneration, } \\
\text { hypogonadotropic hypogonadism (Wortmann this issue) }\end{array}$ & $\begin{array}{l}\text { Synofzik et al, } \\
2014\end{array}$ \\
\hline
\end{tabular}




\begin{tabular}{|c|c|c|c|c|}
\hline $\begin{array}{l}\text { Pantothenate kinase } 2 \\
\text { (AR) } \\
\text { (PANK2) }\end{array}$ & RP & & $\begin{array}{l}\text { Dystonia, dysarthria, rigidity and RP. MRI : bilateral T2 } \\
\text { hypointense deposits in the pallidum centered by T2 } \\
\text { hyperintensities "eye-of-tiger". Acanthocytosis (Tiranti } \\
\text { this issue) }\end{array}$ & $\begin{array}{l}\text { Gregory and } \\
\text { Hayflick } 2011\end{array}$ \\
\hline $\begin{array}{l}\text { Fatty acid hydroxylase } \\
\text { (AR) } \\
\text { (FA2H) }\end{array}$ & RP & $O A$ & $\begin{array}{l}\text { Spastic paraparesis, dystonia, cognitive decline, epilepsy. MRI : } \\
\text { white matter T2 hyperintensities (Tiranti this issue) }\end{array}$ & $\begin{array}{l}\text { Rizzo et al, } \\
2014\end{array}$ \\
\hline $\begin{array}{l}\text { LCHAD /Trifunctional } \\
\text { (AR) } \\
(H A D H A / H A D H B)\end{array}$ & $\mathbf{R P}$ & & $\begin{array}{l}\text { Hypoglycemia, rhabdomyolysis crisis, myocardiopathy, } \\
\text { peripheral neuropathy, retinitis pigmentosa (Spiekerkotter } \\
\text { 2004) }\end{array}$ & $\begin{array}{l}\text { Spiekerkoetter } \\
\text { et al, } 2004\end{array}$ \\
\hline $\begin{array}{l}\text { Abetalipoproteinemia } \\
\text { (AR)(MTP) } \\
\text { Homozygous } \\
\text { hypobetalipoproteinemia } \\
\text { (AR) (APOB) }\end{array}$ & $\mathbf{R P}$ & & $\begin{array}{l}\text { Infantile steatorrhea from fat malabsorption, failure to thrive } \\
\text { and hepatic steatosis. Malabsorption of fat soluble vitamins } \\
\text { leads to retinal degeneration, neuropathy and coagulopathy } \\
\text { (Rader 1993) }\end{array}$ & $\begin{array}{l}\text { Rader et al, } \\
1993\end{array}$ \\
\hline
\end{tabular}




\begin{tabular}{|c|c|c|c|c|}
\hline $\begin{array}{l}\text { Tocopherol carrier deficiency } \\
\text { (AR) } \\
\text { (TTPA) }\end{array}$ & RP & & $\begin{array}{l}\text { Cerebellar ataxia and sensory neuronopathy sometimes } \\
\text { associated with cardiomyopathy and retinitis pigmentosa. } \\
\text { Resembles Friedreich ataxia. }\end{array}$ & Pang et al, 2001 \\
\hline $\begin{array}{l}\text { Dolichol synthesis (AR) } \\
\text { (SRDSA3) } \\
\text { (DHDDS) }\end{array}$ & & OA & $\begin{array}{l}\text { Developmental delay, ataxia and early visual impairment with } \\
\text { optic atrophy, occasional ichthyosiform dermatitis and liver } \\
\text { dysfunction (Lefeber this issue) }\end{array}$ & $\begin{array}{l}\text { Millon et al, } \\
2011\end{array}$ \\
\hline $\begin{array}{l}\text { Dolichol recycling (AR) } \\
\text { (DPM1: CDG1e) } \\
\text { (MPDU1:CDG 1f) }\end{array}$ & & OA & $\begin{array}{l}\text { DPM1phenotype : acquired microcephaly, dysmorphic facial } \\
\text { features, visual loss with optic atrophy, frontal cortical atrophy } \\
\text { and delayed myelination, intractable seizures, hypotonia with } \\
\text { elevated CK. } \\
\text { MPDU1 deficiency : early onset nystagmus and optic atrophy } \\
\text { with early visual loss together with early-onset seizures, } \\
\text { ichthyosis, hypotonia with elevated CK, global developmental } \\
\text { delay, failure to thrive and recurrent vomiting (Lefeber this } \\
\text { issue) }\end{array}$ & $\begin{array}{l}\text { Lefeber et al, } \\
2011\end{array}$ \\
\hline $\begin{array}{l}\text { Amish epilepsy syndrome } \\
\text { (AR) } \\
\text { (ST3GALS) }\end{array}$ & & OA & $\begin{array}{l}\text { Early severe epileptic encephalopathy, pharmacorresistant, } \\
\text { with developmental delay and blindness (Levade this issue) }\end{array}$ & $\begin{array}{l}\text { Fragaki et al, } \\
2013\end{array}$ \\
\hline
\end{tabular}




\begin{tabular}{|c|c|c|c|}
\hline $\begin{array}{l}\text { Mitochondrial membrane } \\
\text { protein-associated } \\
\text { neurodegeneration (MPAN) } \\
\text { (AR) } \\
\text { (C19orf12) }\end{array}$ & OA & $\begin{array}{l}\text { The onset is typically between } 4 \text { and } 20 \text { years of age, and the } \\
\text { progression is generally slower than PKAN and INAD. The clinical } \\
\text { presentation comprises dysarthria and gait difficulties followed } \\
\text { by spasticity, dystonia, parkinsonism, psychiatric symptoms, } \\
\text { motor axonal neuropathy and optic atrophy. MRI: T2 } \\
\text { hypointensities in pallida and substantia nigra }\end{array}$ & $\begin{array}{l}\text { Tiranti this } \\
\text { issue }\end{array}$ \\
\hline $\begin{array}{l}\text { Infantile neuroaxonal } \\
\text { dystrophy (INAD) } \\
\text { (AR) } \\
\text { (PLA2G6) }\end{array}$ & OA & $\begin{array}{l}\text { Motor and mental deterioration, cerebellar ataxia, marked } \\
\text { hypotonia, spastic tetraplegia, and early visual disturbances. } \\
\text { MRI: T2 hypointensities in pallida and substantia nigra }\end{array}$ & $\begin{array}{l}\text { Tiranti this } \\
\text { issue }\end{array}$ \\
\hline $\begin{array}{l}\text { Phospholipase A1 (AR) } \\
(D D H D 2)\end{array}$ & $\begin{array}{c}\quad+ \\
\text { Optic nerve } \\
\text { hypoplasia }\end{array}$ & $\begin{array}{l}\text { Early onset spastic paraplegia, strabismus, dysarthria } \pm \\
\text { dysphagia, developmental delay. MRI: thin corpus callosum, } \\
\text { abnormal NMR lipid peak on MRS }\end{array}$ & $\begin{array}{l}\text { Wortmann this } \\
\text { issue }\end{array}$ \\
\hline $\begin{array}{l}\text { Charcot-Marie-Tooth Disease } \\
\text { associated with early-onset } \\
\text { glaucoma (AR) } \\
(S B F 2)\end{array}$ & Glaucoma & $\begin{array}{l}\text { Demyelinating CMT, mainly characterized by myelin outfoldings } \\
\text { on } \\
\text { nerve biopsies, and early-onset glaucoma. MTMR13 is involved } \\
\text { in phosphoinositide metabolism }\end{array}$ & Azzedine 2003 \\
\hline
\end{tabular}

\section{TABLE 4 Ophtalmological presentations}

Abbreviations: AR: autosomal recessive; AD: autosomal dominant; LCHAD: 3-hydroxy long chain acyl CoA dehydrogenase; PZO: Peroxisome; RP: retinitis pigmentosa; LCA: Leber congenital amaurosis; CRD: cone rod dystrophy; OA: optic atrophy 


\begin{tabular}{|c|c|c|c|c|c|}
\hline MAIN SYMPTOM & AGE AT ONSET & MAJOR ASSOCIATED SYMPTOMS & $\begin{array}{l}\text { DEFECTIVE } \\
\text { ENZYME }\end{array}$ & $\begin{array}{c}\text { DEFECTIVE GENE } \\
\text { (Inheritance) }\end{array}$ & REFERENCES \\
\hline $\begin{array}{l}\text { ICHTHYOSIS } \\
\text { (ARCI) }\end{array}$ & $\begin{array}{l}\text { Congenital to early } \\
\text { infantile } \\
<4 \text { months }\end{array}$ & $\begin{array}{l}\text { Non syndromic autosomal recessive congenital } \\
\text { ichthyosis (ARCI) } \\
\text {-ABCA12 lipid transporter defects may present with } \\
\text { Harlequin ichthyosis (HI), congenital ichthyosiform } \\
\text { erythroderma (CIE) or lamellar ichthyosis type } 2 \text { (LI). LI } \\
\text { patients are born as collodion babies and present a } \\
\text { generalized lamellar ichthyosis with large adherent dark } \\
\text { pigmented scales, with ectropion and palmoplantar } \\
\text { keratoderma. } \\
\text {-ALOX3 /ALOX 12B defects present with non bullous } \\
\text { congenital ichthyosiform erythrodermia (NCIE). Patients } \\
\text { are born as collodion baby. } \\
\text {-CYP4F2 Most of the patients are not born as collodion } \\
\text { babies but present a more erythrodermal status of the } \\
\text { skin at birth. After birth, they present with generalized LI } \\
\text { mostly on the periumbilical region, the lower part of the } \\
\text { body and on the buttocks. Hyperlinearity of palms and } \\
\text { soles similar to that found in ichthyosis vulgaris is } \\
\text { constant. There are scales on the scalps in all patients. } \\
\text {-Phospholipase A1 deficiency born as collodion babies, } \\
\text { later having generalized ichthyosis with fine white scales } \\
\text { and moderate erythroderma and palmoplantar } \\
\text { keratoderma. No lipid vacuoles. }\end{array}$ & $\begin{array}{l}\text { ABCA12 lipid } \\
\text { transporter } \\
\text { Lipoxygenase-3 } \\
\text { 12(R)- Lipoxygenase } \\
\text { CYP4F2 } \\
\text { (leukotriene B4-v- } \\
\text { hydroxylase) } \\
\text { Phospholipase A1 }\end{array}$ & $\begin{array}{l}\text { ABCA12 (AR) } \\
\text { ALOXE3 (AR) } \\
\text { ALOX12 (AR) } \\
\text { FL39501 (AR) } \\
\text { PNPLA1 (AR) }\end{array}$ & $\begin{array}{l}\text { Lefèvre et al, } \\
2003 \\
\text { Akiyama et al, } \\
2010 \\
\text { Jobard et al, } \\
2002 \\
\text { Lefèvre et al, } \\
2006\end{array}$ \\
\hline
\end{tabular}




\begin{tabular}{|c|c|c|c|c|c|}
\hline $\begin{array}{l}\text { ICHTHYOSIS } \\
\text { SYNDROMIC }\end{array}$ & $\begin{array}{l}\text { Congenital to early } \\
\text { infantile } \\
\quad<4 \text { months }\end{array}$ & $\begin{array}{l}\text { Syndromic congenital ichthyosis } \\
\text {-Acute neuronopathic Gaucher disease perinatal form: } \\
\text { Transient collodion baby with severe multivisceral } \\
\text { failure, hydrops foetalis, hepatosplenomegaly, } \\
\text { pancytopenia, arthrogryposis (40\%), brainstem } \\
\text { dysfunction, pyramidal signs, opisthotonos. } \\
\text {-Ceramide synthetase } 3 \text { deficiency: One of the affected } \\
\text { girls presented at birth an extreme ectropion at eclabium } \\
\text { with collodion membrane followed by a moderate } \\
\text { lamellar ichthyosis, scaling of the scalp and a } \\
\text { pronounced keratotic lichenification with prematurely } \\
\text { aged appearance. Four additional Tunisian patients were } \\
\text { affected with a contiguous gene deletion syndrome } \\
\text { involving exon } 13 \text { of CERS3 and ADAMTS17. These } \\
\text { patients presented a combination of the above } \\
\text { ichthyosiform phenotype and the symptoms of Weill- } \\
\text { Marchesini-like syndrome due to ADAMTS17 mutations. } \\
\text { Ichthyosis with spastic paraplegia (SP) } \\
\text { - Sjögren-Larsson syndrome : ichthyosis with severe } \\
\text { pruritis, early hypotonia, generalized scaling sparing the } \\
\text { face, yellow lichenification of neck, flexures, and } \\
\text { abdomen, hypohidrosis, HSP over the first } 2 y, \text { cataracts, } \\
\text { macular dystrophy, mild DD. Brain MRI: delayed } \\
\text { myelination and abnormal lipid peak. Pruritis improved } \\
\text { by Zileuton. } \\
\text { - Neuro-ichythyotic syndrome resembling severe } \\
\text { Sjögren-Larsson syndrome: collodion babies, later having } \\
\text { generalized ichthyosis with predilection to the neck and } \\
\text { diaper areas then to the hands and feet, severe DD, }\end{array}$ & $\begin{array}{l}\text { Fatty acid aldehyde } \\
\text { dehydrogenase }\end{array}$ & ALDH3A2 (AR) & $\begin{array}{l}\text { Willemsen et al, } \\
2001 \\
\text { Aldahmesh et al, } \\
2011\end{array}$ \\
\hline
\end{tabular}




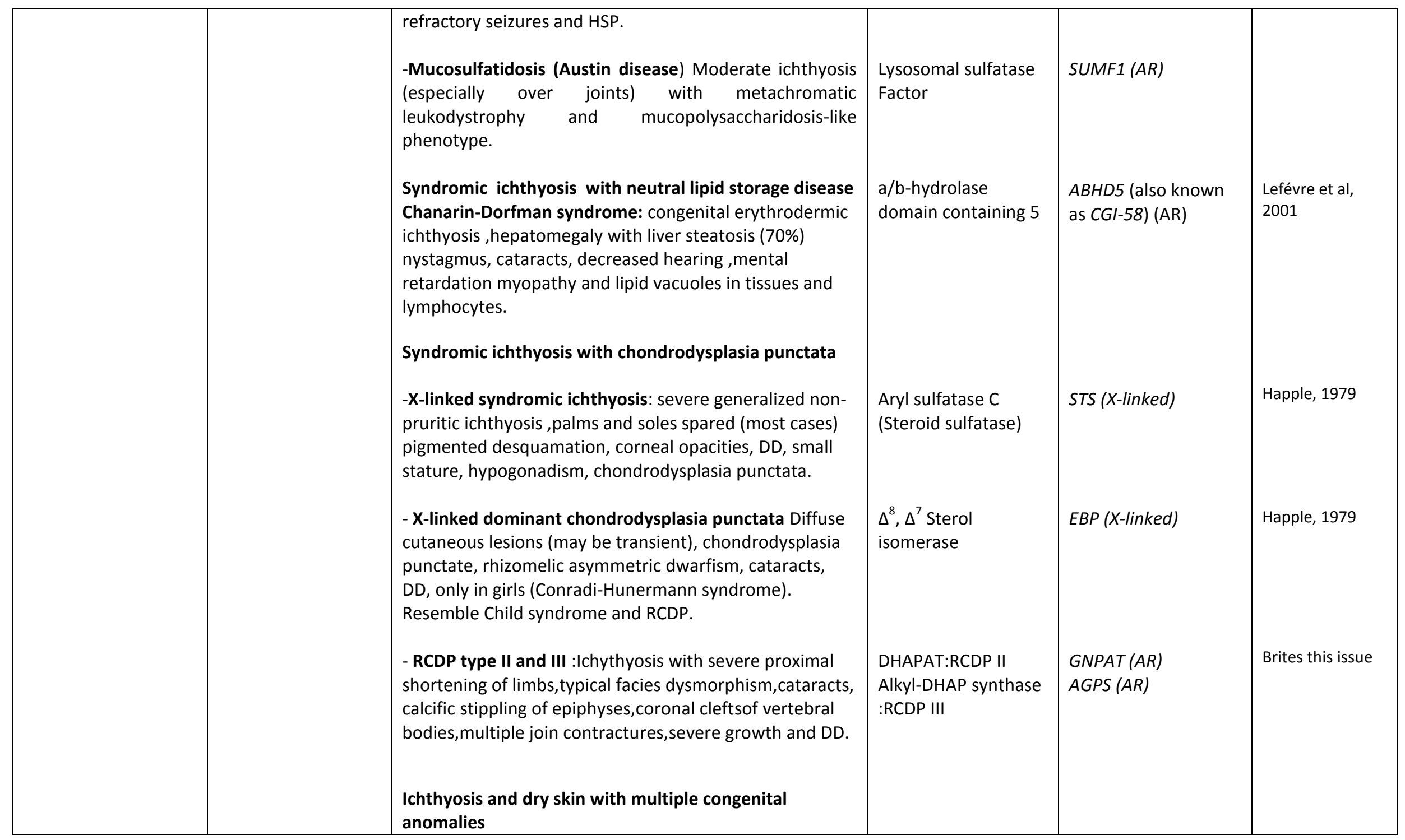




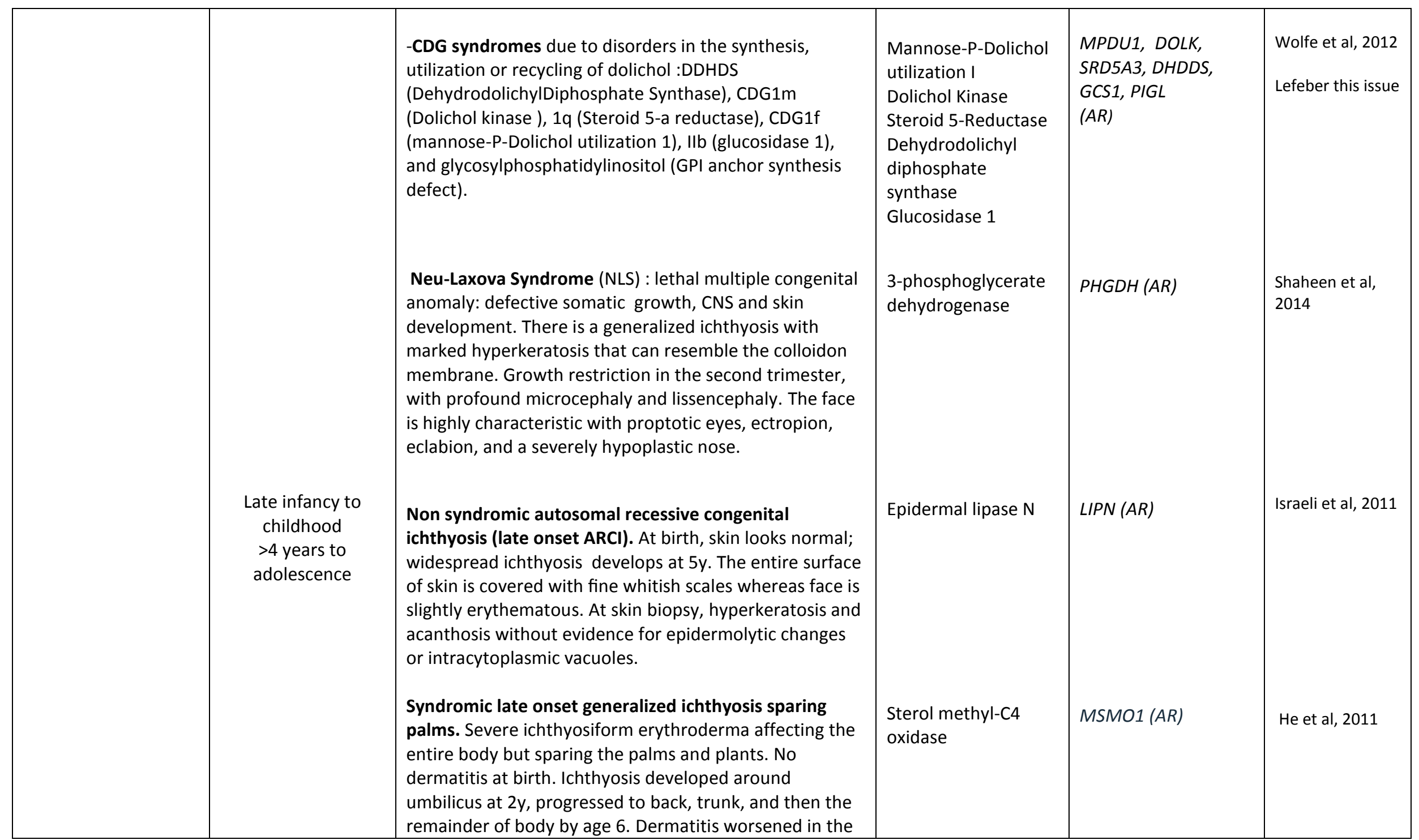




\begin{tabular}{|c|c|c|c|c|c|}
\hline & & $\begin{array}{l}\text { winter, and once almost completely normalized. Patient } \\
\text { also displays congenital cataracts, mild DD, microcephaly } \\
\text { and failure to thrive. Spectacular improvement with } \\
\text { statin and cholesterol supplement. } \\
\text { Late onset neuro-ichthyotic syndromes: } \\
\text {-Refsum disease: Cardinal manifestations include } \\
\text { retinitis pigmentosa, cerebellar ataxia, chronic } \\
\text { polyneuropathy and hyperproteinorachia. Less constant } \\
\text { features are sensorineural hearing loss, anosmia, skeletal } \\
\text { malformations. Involvement of skin is highly variable, } \\
\text { sometimes a presenting sign (children) or absent. } \\
\text { Cutaneous signs range from slightly dry skin especially on } \\
\text { the trunk to florid ichthyosis. Diagnostic based on } \\
\text { phytanic acid accumulation in plasma. } \\
\text {-Serine deficiency with ichthyosis and polyneuropathy } \\
\text { Unique patient who had ichthyosis from the } 1^{\text {st }} \text { year of } \\
\text { life and growth retardation from the age of } 6 y \text { and } \\
\text { presented at the age of } 14 y \text { with an axonal } \\
\text { polyneuropathy. No brain involvement at MRI. Fasting } \\
\text { plasma and CSF serine levels were decreased and the CSF } \\
\text { Glycine slightly increased. Oral ingestion of serine } \\
\text { (400mg/kg/d) cured the skin lesions and polyneuropathy. }\end{array}$ & $\begin{array}{l}\text { Phytanic acid oxidase } \\
\\
\text { Unknown } \\
\text { (hyperactivity of } \\
\text { serine hydroxyl- } \\
\text { methyltransferase) }\end{array}$ & $\begin{array}{l}\text { PHYH (AR) } \\
\text { Unknown }\end{array}$ & $\begin{array}{l}\text { Skjeldal et al, } \\
1987\end{array}$ \\
\hline $\begin{array}{l}\text { HYPER AND HYPO- } \\
\text { PIGMENTED SKIN }\end{array}$ & & $\begin{array}{l}\text { Ceramide synthase } 2 \\
\text { Neuro-cutaneous syndrome combining hyper and hypo- } \\
\text { pigmented skin maculae called 'salt-and-pepper' } \\
\text { syndrome, facial dysmorphism (mid-face hypoplasia, } \\
\text { microcephalia, prominent lower face), scoliosis, severe } \\
\text { DD, seizures, choreoathetosis, spasticity and abnormal } \\
\text { electrocardiogram (non specific conduction changes). }\end{array}$ & $\begin{array}{l}\text { Ceramide synthase } 2 \\
\text { (loss of function GM3 } \\
\text { synthase) }\end{array}$ & $\begin{array}{l}\text { STBGAL5 (AR) } \\
\text { (SIATG) }\end{array}$ & $\begin{array}{l}\text { Boccuto et al, } \\
2014\end{array}$ \\
\hline $\begin{array}{c}\text { ERYTHRO } \\
\text { KERATODERMIA }\end{array}$ & $\begin{array}{l}\text { Early infancy (skin } \\
\text { signs) }\end{array}$ & $\begin{array}{l}\text { ELOVL4 dominant disease: EKV and SCA } \\
2 \text { types of skin lesions may be observed in early }\end{array}$ & Fatty acid elongase & $\begin{array}{l}\text { ELOVL4 (AD) } \\
\text { Heterozygous }\end{array}$ & $\begin{array}{l}\text { Cadieux-Dion et } \\
\text { al, } 2014\end{array}$ \\
\hline
\end{tabular}




\begin{tabular}{|c|c|c|c|c|c|}
\hline VARIABILIS (EKV) & $\begin{array}{l}4^{\text {th }} \text { to } 5^{\text {th }} \text { decades } \\
\text { (neurologic signs) }\end{array}$ & $\begin{array}{l}\text { infancy .First, erythematous and hyperkeratotic plaques } \\
\text { over the dorsal aspects of the hands and feet, the } \\
\text { elbows, the ankles, and the external ears. The } \\
\text { hyperkeratosis usually is more prominent than the } \\
\text { erythema. Second, transient, figurate, and erythematous } \\
\text { patches are observed over the legs, thighs, and buttocks. } \\
\text { Both types of lesions are symmetrically distributed and } \\
\text { vary in severity. The lesions disappear after the patient is } \\
25 \text { years of age. The onset of gait ataxia usually occurred } \\
\text { in the fourth or fifth decade of life. The progression of } \\
\text { gait disturbance is very slow. }\end{array}$ & & & \\
\hline $\begin{array}{c}\text { CONGENITAL } \\
\text { GENERALIZED } \\
\text { LIPODYSTROPHY }\end{array}$ & Congenital & $\begin{array}{l}\text { Berardinelli Seip Syndrome } \\
\text { Congenital generalized lipodystrophy, lack of body fat } \\
\text { since birth, striking muscular appearance, } \\
\text { hyperinsulinemia, hypertriglyceridemia, accelerated } \\
\text { growth, hepatomegaly with liver steatosis, diabetes } \\
\text { mellitus at puberty, acanthosis nigricans, acromegaloid } \\
\text { appearance and occasional cardiomyopathy. }\end{array}$ & $\begin{array}{l}\text { 1-acylglycerol-3- } \\
\text { phosphate } \\
\text { O-acyltransferase }\end{array}$ & AGPAT2 (AR) & $\begin{array}{l}\text { Debray et al } \\
2013\end{array}$ \\
\hline $\begin{array}{l}\text { INFLAMMATORY } \\
\text { DERMATOSIS }\end{array}$ & Infancy to childhood & $\begin{array}{l}\text { Majeed syndrome: } \\
\text { Autoinflammatory disorder characterized by an } \\
\text { Inflammatory dermatosis (pustulosis palmoplantaris, } \\
\text { Sweet syndrome, psoriasis), chronic recurrent multifocal } \\
\text { aseptic osteomyelitis, periodic fever and congenital } \\
\text { dyserythropoietic anemia (microcytosis both peripherally } \\
\text { and in the bone marrow).May resemble Gaucher disease. }\end{array}$ & $\begin{array}{l}\text { Phosphatidate } \\
\text { phosphatase } 2 \\
\text { (Lipin2) }\end{array}$ & LPIN2 (AR) & $\begin{array}{l}\text { Ferguson PJ et al } \\
\text { J Med Genet } \\
2005\end{array}$ \\
\hline
\end{tabular}

\section{TABLE 5 Dermatological presentations}

\section{Abbreviations:}

AR: autosomal recessive; AD: autosomal dominant; ARCI: autosomal recessive congenital ichthyosis. DD: Developmental delay; ELOVL: elongase/elongation of very long chain fatty acids deficiency. FALDH: Fatty aldehyde dehydrogenase deficiency. GPI: glycosylphosphatidylinositol. HSP: hereditary spastic paraparesis; SLS: Sjögren-Larsson syndrome. 


\begin{tabular}{|c|c|c|c|c|}
\hline $\begin{array}{c}\text { Syndrome } \\
\text { enzyme defect }\end{array}$ & Major symptoms & Enzyme & Gene & Reference \\
\hline Majeed syndrome (AR) & $\begin{array}{l}\text { Onset in infancy to childhood: auto-inflammatory } \\
\text { disorder, chronic recurrent multifocal aseptic } \\
\text { osteomyelitis with osteolytic and sclerotic lesions, periodic } \\
\text { fever,inflammatory dermatosis, dyserythropoietic anemia }\end{array}$ & $\begin{array}{l}\text { Phosphatidic } \\
\text { phosphatase } \\
\text { (Lipin 2) }\end{array}$ & LPN2 & $\begin{array}{l}\text { Ferguson et al } \\
2005\end{array}$ \\
\hline $\begin{array}{l}\text { Gaucher disease type } 1 \\
\text { (AR) }\end{array}$ & $\begin{array}{l}\text { Bone involvement is an important concern in late } \\
\text { childhood to adulthood. Medullary infarction of long } \\
\text { bones may cause excruciating pain ("bone crisis"). Aseptic } \\
\text { necrosis of femoral head and spontaneous fractures due } \\
\text { to osteopenia are common findings and can be inaugural. }\end{array}$ & $\begin{array}{c}\text { Glucocerebrosidase } \\
\text { type } 1\end{array}$ & GBA & Vanier 2012 \\
\hline $\begin{array}{l}\text { Phosphocholine } \\
\text { Citidylyl transferase } \\
\text { deficiency (AR) }\end{array}$ & $\begin{array}{l}\text { Spondylometaphyseal dysplasia (short stature with } \\
\text { rhizomelia, platyspondyly, metaphyseal irregularity, } \\
\text { bowing of long bones) with cone-rod dystrophy. }\end{array}$ & $\begin{array}{l}\text { Phosphocholine } \\
\text { citidylyl transferase } \\
\text { (alpha isoform) }\end{array}$ & PCYT1A & $\begin{array}{l}\text { Wortmann } \\
\text { this issue }\end{array}$ \\
\hline $\begin{array}{l}\text { Lenz Majewski } \\
\text { hyperostotic dwarfism } \\
\text { syndrome (AD) }\end{array}$ & $\begin{array}{l}\text { Progressive generalized hyperostosis leading to severe } \\
\text { growth restriction, typical craniofacial dysmorphic } \\
\text { features (thickness of the jaw, clavicles and ribs), distal- } \\
\text { limb abnormalities (proximal symphalangism), cutis laxa, } \\
\text { intellectual disability. }\end{array}$ & $\begin{array}{l}\text { Phosphatidylserine } \\
\text { synthase } 1 \\
\text { gain-of-function }\end{array}$ & PTDSS1 & $\begin{array}{l}\text { Wortmann } \\
\text { this issue }\end{array}$ \\
\hline Opsismodysplasia (AR) & $\begin{array}{l}\text { Chondrodysplasia characterized by pre- and postnatal } \\
\text { micromelia with extremely short hands and feet. The main } \\
\text { radiological features are severe platyspondyly, squared } \\
\text { metacarpals, extreme delayed skeletal ossification and } \\
\text { metaphyseal cupping. }\end{array}$ & $\begin{array}{c}\text { Inositol } \\
\text { polyphosphate } \\
\text { phosphatase-like } 1\end{array}$ & INPPL1 & $\begin{array}{l}\text { Cormier-Daire } \\
2003 \\
\text { Huber } 2013 \\
\text { Below } 2013\end{array}$ \\
\hline $\begin{array}{l}\text { Yunis-Varon syndrome } \\
\text { (AR) }\end{array}$ & $\begin{array}{l}\text { Wide fontanels with calvarial dysostosis, aplasia or } \\
\text { hypoplasia of the clavicles and phalanges in the hands and } \\
\text { feet, absence of thumbs and halluces. Pelvic bone } \\
\text { dysplasia, absent sternal ossification centers and fractures } \\
\text { are also frequent. Common features include diffuse brain } \\
\text { atrophy, sparse and pale hair, facial dysmorphism. }\end{array}$ & $\begin{array}{l}\text { Phosphoinositide } \\
\text { phosphatase (FIG4) } \\
\text { (required for the } \\
\text { regulation of } \\
\text { PI(3,5)P2 levels) }\end{array}$ & PIK3R2 & $\begin{array}{c}\text { Campeau } \\
2013\end{array}$ \\
\hline
\end{tabular}




\begin{tabular}{|c|c|c|c|c|}
\hline SHORT syndrome (AD) & $\begin{array}{l}\text { Short stature, hyperextensibility, hernia, ocular } \\
\text { depression, Rieger anomaly and teething delay. }\end{array}$ & $\begin{array}{l}\text { Phosphoinositide } \\
\text { kinase (PIK) }\end{array}$ & PIK3R1 & $\begin{array}{l}\text { Thauvin- } \\
\text { Robinet } \\
2013\end{array}$ \\
\hline $\begin{array}{l}\text { Phosphoinositide } \\
\text { kinase } 3\end{array}$ & $\begin{array}{l}\text { Megalencephaly, polymicrogeria, polydactyly, } \\
\text { hydrocephalus syndrome. }\end{array}$ & $\begin{array}{l}\text { Phosphoinositide } \\
\text { kinase (PIK) }\end{array}$ & FIG4 & Gross 2014 \\
\hline $\begin{array}{l}\text { PIK3CA-related } \\
\text { segmental overgrowth } \\
\text { disorders. } \\
\text { (Somatic mutations in the } \\
\text { phosphatidylinositol/AKT/ } \\
\text { mTOR pathway) }\end{array}$ & $\begin{array}{l}\text { Congenital asymmetric disproportionate overgrowth - } \\
\text { mild with little postnatal progression in most, severe and } \\
\text { progressive requiring multiple surgeries in others. } \\
\text { Overgrowth affects the lower extremities more than the } \\
\text { upper extremities and progresses in a distal to proximal } \\
\text { pattern. Congenital lipomatosis is present in all patients } \\
\text { and, in the most severely affected patients, is associated } \\
\text { with marked paucity of adipose tissue in unaffected areas. }\end{array}$ & & $\begin{array}{c}\text { PIK3CA } \\
\text { (somatic } \\
\text { mutations) }\end{array}$ & $\begin{array}{l}\text { Keppler- } \\
\text { Noreuil } \\
2014\end{array}$ \\
\hline $\begin{array}{l}\text { Rhizomelic } \\
\text { chondrodysplasia } \\
\text { punctata (RCDP) } \\
\text { type I-II-III (AR) }\end{array}$ & $\begin{array}{l}\text { Severe proximal shortening of limbs, facial dysmorphism, } \\
\text { cataracts, calcific stippling of epiphyses, coronal clefts of } \\
\text { vertebral bodies, multiple joint contractures, growth and } \\
\text { psychomotor delays, ichthyosis. The chondrodysplasia } \\
\text { punctata may involve extra-skeletal tissues. }\end{array}$ & $\begin{array}{l}\text { PTS2 (type I) } \\
\text { DHAPAT (type 2) } \\
\text { Alkyl-DHAP synthase } \\
\text { (type 3) }\end{array}$ & $\begin{array}{l}\text { PEX7 } \\
\text { GNPAT } \\
\text { AGPS }\end{array}$ & Poll The 2012 \\
\hline $\begin{array}{l}\text { PZO Biogenesis defects } \\
\text { (AR) }\end{array}$ & $\begin{array}{l}\text { Classical Zellweger syndrome may present with } \\
\text { chondrodysplasia punctata less widespread than in RCDP. }\end{array}$ & Several peroxins & $\begin{array}{c}\text { PEX } \\
\text { genes }\end{array}$ & Poll The 2012 \\
\hline Refsum disease (AR) & $\begin{array}{l}\text { Skeletal malformations in } 50 \% \text { of patients: symmetric } \\
\text { epiphyseal dysplasia in the knee, joints, elbows and } \\
\text { shoulders; bilateral shortening or elongation of the } 3^{\text {rd }} \text { and } \\
4^{\text {th }} \text { metatarsal bones, syndactyly and shortened digits. }\end{array}$ & $\begin{array}{l}\text { Phytanic acid } \\
\text { hydroxylase }\end{array}$ & PHYH & $\begin{array}{c}\text { Skjeldal } \\
1987\end{array}$ \\
\hline $\begin{array}{l}\text { Conradi-Hünermann } \\
\text { (X-linked dominant) } \\
\text { (CDPX 2) }\end{array}$ & $\begin{array}{l}\text { Patients (girls) with short stature, asymmetric rhizomelic } \\
\text { shortening of the limbs, calcific stippling of the epiphyseal } \\
\text { regions and craniofacial defects. Associated with } \\
\text { ichthyosiform erythroderma in the neonate, atrophic and } \\
\text { pigmentary lesions in childhood, and coarse lusterless hair } \\
\text { and alopecia in adults, and cataracts. }\end{array}$ & $\begin{array}{l}\text { Sterol } \Delta^{8}-\Delta^{7} \\
\text { isomerase }\end{array}$ & $E B P$ & $\begin{array}{l}\text { Waterham } \\
2006 \\
\text { Braverman } \\
1999 \\
\text { Derry } 1999\end{array}$ \\
\hline
\end{tabular}




\begin{tabular}{|c|c|c|c|c|}
\hline $\begin{array}{l}\text { Child syndrome } \\
\text { (X-linked dominant)) }\end{array}$ & $\begin{array}{l}\text { CHILD syndrome (congenital hemidysplasia with } \\
\text { ịchtyosiform erythroderma and limb defects) presents } \\
\text { with skin and skeletal abnormalities similar to those } \\
\text { observed in CDPX2 patients but with a striking unilateral } \\
\text { distribution affecting the right side of the body more often } \\
\text { than the left. Alopecia, nail involvement and limb } \\
\text { reduction defects with calcific stippling of the epiphysis } \\
\text { are common on the affected side. There is no cataract. }\end{array}$ & $\begin{array}{l}\text { 3 } \beta \text {-hydroxysterol } \\
\text { dehydrogenase }\end{array}$ & NSDHL & $\begin{array}{l}\text { Waterham } \\
2006\end{array}$ \\
\hline $\begin{array}{l}\text { Smith Lemli Opitz } \\
\text { (SLOS syndrome) (AR) }\end{array}$ & $\begin{array}{l}\text { Variable spectrum of morphogenic and congenital } \\
\text { anomalies: characteristic craniofacial appearance and limb } \\
\text { abnormalities including cutaneous syndactyly of the } 2^{\text {nd }} \\
\text { and 3rd toes, postaxial polydactyly and short proximally } \\
\text { placed thumbs. }\end{array}$ & $\begin{array}{l}\text { 7-dehydro } \\
\text { cholesterol } \\
\text { reductase }\end{array}$ & DHCR7 & $\begin{array}{l}\text { Waterham } \\
2006\end{array}$ \\
\hline Desmosterolosis (AR) & $\begin{array}{l}\text { Short limb, osteosclerosis, dysmorphic facial features, } \\
\text { microcephaly, profound developmental delay and brain } \\
\text { malformations including agenesis of the corpus callosum. }\end{array}$ & $\begin{array}{c}\text { 3 } \beta \text {-hydroxysterol } \\
\Delta^{24} \text {-reductase }\end{array}$ & DHCR24 & $\begin{array}{l}\text { Waterham } \\
2006\end{array}$ \\
\hline Lathosterolosis (AR) & $\begin{array}{l}\text { Only two patients reported who presented at birth with } \\
\text { postaxial hexadactyly, syndactyly, craniofacial } \\
\text { dysmorphism, severe microcephaly and SLOS-like } \\
\text { features. }\end{array}$ & sterol $\Delta^{5}$-desaturase & SC5D & $\begin{array}{l}\text { Waterham } \\
2006\end{array}$ \\
\hline $\begin{array}{l}\text { Greenberg skeletal } \\
\text { dysplasia } \\
\text { (AR) }\end{array}$ & $\begin{array}{l}\text { Severe fetal hydrops, short-limb dwarfism, unusual 'moth- } \\
\text { eaten' appearance of the markedly shortened long bones, } \\
\text { bizarre ectopic ossification centers and marked } \\
\text { disorganization of chondro-osseous histology. May } \\
\text { present with polydactyly and non skeletal malformations } \\
\text { (HEM skeletal dysplasia) }\end{array}$ & $\begin{array}{c}3 \beta \text {-hydroxysterol } \\
\text { sterol } \Delta^{14} \text {-reductase }\end{array}$ & LBR & $\begin{array}{l}\text { Waterham } \\
2006\end{array}$ \\
\hline
\end{tabular}


TABLE 6 Orthopedic presentations

Abbreviations:

AR: autosomal recessive; $A D$ :autosomal dominant;;PZO :Peroxisome 


\begin{tabular}{|c|c|c|c|c|c|}
\hline $\begin{array}{c}\text { HEPATIC } \\
\text { involvement }\end{array}$ & $\begin{array}{l}\text { AGE AT } \\
\text { ONSET }\end{array}$ & MAJOR ASSOCIATED SYMPTOMS & $\begin{array}{l}\text { DEFECTIVE } \\
\text { ENZYME }\end{array}$ & $\begin{array}{l}\text { DEFECTIVE } \\
\text { GENE }\end{array}$ & REFERENCES \\
\hline $\begin{array}{l}\text { Transient neonatal } \\
\text { cholestatic jaundice } \\
\text { and/or liver failure } \\
\text { followed by } \\
\text { neurodegenerative } \\
\text { disorder }\end{array}$ & $\begin{array}{l}\text { Neonatal to } \\
\text { first } 6 \text { months } \\
\text { First } 6 \text { months }\end{array}$ & $\begin{array}{l}\text { Niemann Pick disease type C About } 1 / 3 \text { of the NP-C patients have a } \\
\text { prolonged neonatal cholestatic icterus with hepatosplenomegaly. In } \\
\text { most patients, the icterus resolves spontaneously, and only } \\
\text { hepatosplenomegaly remains, but in a few patients, the liver disease } \\
\text { worsens and they die from hepatic failure before } 6 \text { months. Isolated } \\
\text { hepatosplenomegaly or splenomegaly can also develop at this age. } \\
\text { Filipin staining test is positive } \\
\text { MEG(H)DEL syndrome (H=Hepatic) At } 24-48 \text { hr of life, patients } \\
\text { present with hypotonia and liver dysfunction including symptomatic } \\
\text { hypoglycemia, lactic acidosis, elevated serum transaminase and } \text {-GT } \\
\text { levels, coagulopathy, hyperammonemia and markedly elevated } \\
\text { serum a -fetoprotein. Filipin staining test is positive. During the } 1 \text { st } \\
\text { year of life, a few episodes of liver dysfunction may occur. At } 6 \\
\text { months of age, failure to thrive and hypotonia become prominent. } \\
\text { From age } 13 \text { to } 22 \text { months, neurological abnormalities characteristic } \\
\text { of the MEGDEL syndrome develop. } \\
\text { Infantile Refsum disease and peroxisomal biogenesis defects During } \\
\text { this period of life, the predominant symptoms may be hepatomegaly } \\
\text { associated (or not associated) with prolonged jaundice, liver failure } \\
\text { and nonspecific digestive problems (anorexia, vomiting, diarrhea) } \\
\text { leading to failure to thrive and osteoporosis. Hypocholesterolemia, } \\
\text { hypolipoproteinemia and decreased levels of fat-soluble vitamins, } \\
\text { symptoms that resemble a malabsorption syndrome, are frequently } \\
\text { observed. These patients can be erroneously diagnosed as having a } \\
\text { congenital defect of glycosylation or a defect of the OXPHOS } \\
\text { respiratory chain. }\end{array}$ & Several Peroxins & $\begin{array}{l}\text { NPC1-NPC2) } \\
\text { SERAC1 } \\
\text { Several PEX }\end{array}$ & $\begin{array}{l}\text { Wortmann } \\
2012 \\
\text { Sarig } 2013 \\
\text { Wortmann this } \\
\text { issue }\end{array}$ \\
\hline
\end{tabular}




\begin{tabular}{|c|c|c|c|c|}
\hline & $\begin{array}{l}\text { Cerebrotendinous xanthomatosis (CTX) Cholestatic jaundice in } \\
\text { infancy may be the first manifestation of CTX. However, it usually } \\
\text { improves spontaneously. The next (or the first) symptom of CTX is } \\
\text { often psychomotor delay detected during the first decade of life. } \\
\text { Cataract may also be present as early as } 5 \text { years of age. Some } \\
\text { patients present with persistent diarrhea from early childhood. } \\
\text { Motor dysfunction (spastic paresis, cerebellar ataxia) frequently } \\
\text { develops in the second or third decade of life. Xanthomata are } \\
\text { observed within the second decade. } \\
\text { á-Methylacyl-CoA Racemase Deficiency (AMACR) Neonatal } \\
\text { cholestatic liver disease was documented in an infant with AMACR } \\
\text { deficiency who presented with a coagulopathy due to vitamin K } \\
\text { deficiency; a sibling had died of a major bleed with the same cause. } \\
\text { The infant had mild cholestatic jaundice with raised aspartate } \\
\text { aminotransferase and, in contrast to 3â-dehydrogenase deficiency, } \\
\text { 5â-reductase deficiency and CTX, elevated ã-GT. } \\
\text { Oxysterol 7á-Hydroxylase Deficiency Oxysterol 7á-hydroxylase may } \\
\text { present in the first } 3 \text { months of life with severe cholestasis, cirrhosis } \\
\text { and liver synthetic failure. One infant presented with liver failure and } \\
\text { hypoglycaemia at } 3 \text { months but recovered completely with } \\
\text { chenodeoxycholic acid treatment. Oxysterol 7á-hydroxylase deficiency } \\
\text { has also been identified as a cause of a recessive form of hereditary } \\
\text { spastic paraplegia (SPG type 5). } \\
\text { LCHAD deficiency. A few patients with LCHAD deficiency present in } \\
\text { the first } 3 \text { months of life with transient cholestatic jaundice followed } \\
\text { by the classic manifestation of LCHAD disease (recurrent attacks of } \\
\text { hypoglycemia and myoglobinuria, cardiac features, peripheral } \\
\text { neuropathy and retinitis pigmentosa) }\end{array}$ & $\begin{array}{l}\text { Oxysterol 7 } \alpha- \\
\text { Hydroxylase } \\
\\
\text { 3-Hydroxy long } \\
\text { chain acyl-coA } \\
\text { dehydrogenase }\end{array}$ & $\begin{array}{l}\text { AMACR } \\
\text { CYP7B1 } \\
\\
\text { HADHA/HAD } \\
\text { HB }\end{array}$ & $\begin{array}{l}\text { Clayton } 2002 \\
\\
\text { Van Veldhoven } \\
2001 \\
\text { Setchell } 2003 \\
\\
\\
\\
\text { Setchell } 1998 \\
\text { Tsaousidou } \\
2008\end{array}$ \\
\hline
\end{tabular}




\begin{tabular}{|c|c|c|c|c|c|}
\hline & & & & & Odievre 2002 \\
\hline & $\begin{array}{l}\text { First weeks of } \\
\text { life }\end{array}$ & $\begin{array}{l}\text { Wolman disease presents in the } 1^{\text {st }} \text { week of life with poor feeding, } \\
\text { vomiting, diarrhea, severe failure to thrive, abdominal distension, } \\
\text { hepatosplenomegaly with mesenteric adenopathy and bilateral } \\
\text { adrenal calcifications at abdominal ultrasound. The psychomotor } \\
\text { development is normal. } \\
\text { Classic Niemann-Pick Disease Type A. Presents with vomiting and } \\
\text { diarrhea, failure to thrive, prominent and progressive } \\
\text { hepatosplenomegaly and lymphadenopathy, in most cases before 3-4 } \\
\text { months of age and sometimes earlier. Hypotrophy is a frequent } \\
\text { finding. Neurological examination is essentially normal until the age }\end{array}$ & $\begin{array}{l}\text { Acid Lipase } \\
\text { Acid } \\
\text { Sphingomyelinase }\end{array}$ & LIPA & Vanier 2013 \\
\hline
\end{tabular}




\begin{tabular}{|c|c|c|c|c|c|}
\hline & $\begin{array}{l}\text { Late infancy } \\
\text { to adulthood }\end{array}$ & $\begin{array}{l}\text { of 5-10 months, when the child shows hypotonia, progressive loss of } \\
\text { acquired motor skills, lack of interest in the surroundings and } \\
\text { reduction of spontaneous movements. } \\
\text { GM1 gangliosidosis (Landing disease) The typical early infantile form } \\
\text { (or type 1) presents with hypotonia in the first days or weeks of life, } \\
\text { with poor head control. The arrest in neurological development is } \\
\text { observed at 3-6 months of age. Feeding difficulties and failure to thrive } \\
\text { are common. Many infants have facial and peripheral edema. In typical } \\
\text { cases, dysmorphic features resembling Hurler syndrome may be } \\
\text { present. Hepatomegaly and later splenomegaly are almost always } \\
\text { present. Dorsolumbar kyphoscoliosis is common. } \\
\text { Prosaposin deficiency presents as a severe neurovisceral storage } \\
\text { disease manifesting immediately after birth with rapidly fatal course } \\
\text { and death between } 4 \text { and } 17 \text { weeks of age. The patients have } \\
\text { hepatosplenomegaly, hypotonia, massive myoclonic bursts, abnormal } \\
\text { ocular movements, dystonia and seizures. } \\
\text { Niemann Pick disease type B chronic, non-neuronopathic disease } \\
\text { presents typically with splenomegaly or hepatosplenomegaly in late } \\
\text { infancy or childhood but discovery may occur at any point from birth } \\
\text { until late adulthood. Bruising and epistaxis are frequent. } \\
\text { Hypersplenism may occur. The most constant associated signs are } \\
\text { radiographic abnormalities of the lung (diffuse, reticulonodular } \\
\text { infiltrations) and interstitial lung disease with variable impairment of } \\
\text { pulmonary function. }\end{array}$ & $\begin{array}{l}\text { Prosaposin } \\
\text { Acid } \\
\text { Sphingomyelinase }\end{array}$ & $\begin{array}{l}\text { PSAP } \\
\text { SMPD1 }\end{array}$ & $\begin{array}{l}\text { Vaccaro et al, } \\
2010\end{array}$ \\
\hline $\begin{array}{l}\text { With inflammatory } \\
\text { crisis and anemia }\end{array}$ & First year & $\begin{array}{l}\text { Mevalonate kinase deficiency present with characteristic episodes of } \\
\text { high fever and inflammation with abdominal pain, vomiting, diarrhea, } \\
\text { lymphadenopathy, hepatosplenomegaly, skin rash and recurrent non } \\
\text { regenerative anemia. }\end{array}$ & Mevalonate kinase & $M V K$ & Houten 2003 \\
\hline
\end{tabular}




\begin{tabular}{|c|c|c|c|c|c|}
\hline Hepatic steatosis & Early infantile & $\begin{array}{l}\text { Chanarin-Dorfman Syndrome Congenital erythrodermic ichthyosis, } \\
\text { hepatomegaly with liver steatosis (70\%), nystagmus, cataracts, } \\
\text { decreased hearing, mental retardation, myopathy, non-lysosomal } \\
\text { lipid storage disease .Tissular accumulation of neutral lipids } \\
\text { (vacuoles). } \\
\text { Berardinelli Seip Syndrome. Congenital generalized lipodystrophy } \\
\text { Striking muscular appearance, hyperinsulinemia (insulin resistance), } \\
\text { hypertriglyceridemia, accelerated growth, hepatomegaly with liver } \\
\text { steatosis. } \\
\text { Triglyceride lipase deficiency. Neutral lipid storage with } \\
\text { myopathy of proximal and distal muscles, asymmetric muscle } \\
\text { atrophy, hepatomegaly and liver steatosis (50\%). } \\
\text { Glycerol-3-phosphate dehydrogenase deficiency Early infantile } \\
\text { moderate to massive hepatomegaly and steatosis, abnormal liver } \\
\text { function tests, transient infantile hypertriglyceridemia ,and } \\
\text { development of hepatic fibrosis. Normal neurologic examination. } \\
\text { One patient with microcephaly. } \\
\text { Phosphate cytidylyltransferase } 1 \text { alpha deficiency. Late childhood } \\
\text { presentation with severe nonalcoholic fatty liver disease, low HDL } \\
\text { cholesterol levels, lipodystrophy, severe insulin resistance, diabetes } \\
\text { and short stature without any spondylometaphyseal dysplasia and } \\
\text { visual impairment (no cone-rod retinal dystrophy). }\end{array}$ & $\begin{array}{l}\text { a/b-hydrolase } \\
\text { domain containing } \\
5 \\
\text { 1-acylglycerol-3- } \\
\text { phosphateO- } \\
\text { acyltransferase } \\
\text { Patatin-like } \\
\text { Phospholipase } \\
\text { Glycerol-3- } \\
\text { phosphate } \\
\text { dehydrogenase } 1 \\
\end{array}$ & $\begin{array}{l}\text { ABHD5 } \\
\text { AGPAT2 } \\
\text { PNPLA2 } \\
\text { GPD1 } \\
\text { PCYT1A }\end{array}$ & $\begin{array}{l}\text { Mitchell this } \\
\text { issue } \\
\text { Mitchell this } \\
\text { issue } \\
\text { Basel- } \\
\text { Vanagaite } \\
2012 \\
\text { Joshi } 2014 \\
\text { Mitchell this } \\
\text { issue } \\
\text { Payne } 2014\end{array}$ \\
\hline
\end{tabular}

\section{TABLE 7 Hepatic presentations}


Click here to download Table: suppl Table overview .docx

\begin{tabular}{|c|c|c|c|c|c|c|c|}
\hline CNS & PNS & Muscle & Ophthal. & Skin & Orthop. & Hepatic & Others \\
\hline ALDH3A2 & $\mathrm{ABCD} 1$ & ABHD5 & ABCA4 & ABCA12 & AGPS & ABHD5 & COQ2 \\
\hline ARSI & ABHD12 & AGK & ABHD12 & ABHD5 & DHCR24 & AGPAT2 & COQ9 \\
\hline B4GALNT1 & AMACR & AMACR & ABHD5 & AGPAT2 & DHCR7 & AMACR & DGKE \\
\hline COASY & ARSI & CHKB & AGK & AGPS & EBP & CYP27A1 & INPP5E \\
\hline COQ1 & ATL1 & COQ4 & ALDH3A2 & ALDH3A2 & FIG4 & CYP7B1 & OCRL \\
\hline COQ2 & B4GALNT1 & COQ9 & AMACR & ALOX12 & GBA & GBA & PEX genes \\
\hline COQ4 & COQ1 & DK1 & APOB & ALOXE3 & GNPAT & GLB1 & PIK3R1 \\
\hline coQ6 & DNMT1 & DPM1 & B4GALNT1 & CERS3 & INPPL1 & GPD1 & PLCE1 \\
\hline COQ8 & HADHA & DPM2 & C19orf12 & CYP4F22 & LBR & HADHA & PLCG2 \\
\hline COQ9 & HADHB & DPM3 & CERKL & DHDDS & LPIN2 & HADHB & \\
\hline CYP2U1 & PEX genes & HADHA & CYP27A1 & DOLK & NSDHL & LIPA & \\
\hline DDHD1 & PEX7 & HADHB & CYP4V2 & EBP & PCYT1A & MVK & \\
\hline DDHD2 & $\mathrm{PHYH}$ & LPIN1 & CoQ1 & ELOVL4 & PEX genes & NPC1 & \\
\hline ELOVL4 & PNPLA6 & MPDU1 & DDHD2 & GBA & PEX7 & NPC2 & \\
\hline $\mathrm{FA} 2 \mathrm{H}$ & RAB7A & PNPLA2 & DHCR7 & GNPAT & $\mathrm{PHYH}$ & PCYT1A & \\
\hline GBA2 & SLC5A7 & PTPLA & DHDDS & LIPN & PIK3CA & PEX genes & \\
\hline $\begin{array}{l}\text { GBA2 } \\
\text { PANK2 }\end{array}$ & SPTLC1 & TAZ & DPM1 & LPIN2 & PIK3R1 & PNPLA2 & \\
\hline PGAP1 & SPTLC2 & & EBP & MPDU1 & PIK3R2 & PSAP & \\
\hline PGAPI & & & ELOVL4 & MSMO1 & PTDSS1 & SERAC1 & \\
\hline PGAP2 & & & $\mathrm{FA} 2 \mathrm{H}$ & PHGDH & SC5D & SMPD1 & \\
\hline PGAP3 & & & GBA2 & PHYH & & & \\
\hline PIGA & & & HADHA & PIGL & & & \\
\hline PIGL & & & HADHB & PNPLA1 & & & \\
\hline PIGM & & & INPP5E & SRD5A3 & & & \\
\hline PIGN & & & LRAT & ST3GAL5 & & & \\
\hline PIGO & & & MPDU1 & STS & & & \\
\hline PIGV & & & MVK & SUMF1 & & & \\
\hline PIGW & & & OCRL & & & & \\
\hline PLA2G6 & & & PANK2 & & & & \\
\hline PNPLA6 & & & PCYT1A & & & & \\
\hline SERAC1 & & & PEX genes & & & & \\
\hline \multirow[t]{16}{*}{ ST3GAL5 } & & & PHGDH & & & & \\
\hline & & & PHYH & & & & \\
\hline & & & PITPNM3 & & & & \\
\hline & & & PLA2G6 & & & & \\
\hline & & & PNPLA5 & & & & \\
\hline & & & RBP3 & & & & \\
\hline & & & RBP4 & & & & \\
\hline & & & $\mathrm{RDH} 11$ & & & & \\
\hline & & & $\mathrm{RDH} 12$ & & & & \\
\hline & & & RDH5 & & & & \\
\hline & & & RPE65 & & & & \\
\hline & & & SBF2 & & & & \\
\hline & & & SLC33A1 & & & & \\
\hline & & & SRD5A3 & & & & \\
\hline & & & ST3GAL5 & & & & \\
\hline & & & TTPA & & & & \\
\hline
\end{tabular}

Supplementary Table: Gene defects in the lipid metabolism and their predominant clinical manifestation. 